\title{
11 The Rise of a Political Strongman in Dergé in the Early Twentieth Century
}

\author{
The Story of Jagö Topden
}

Yudru Tsomu

\begin{abstract}
This chapter discusses the emergence of a new elite class of 'political strongmen' in Kham in the late nineteenth and early twentieth centuries. The case of Jagö Topden demonstrates a shift from authority based on traditional hereditary and ascribed status to political recognition achieved through diverse political strategies, based on individual charisma, ambition, and consummate political skills. Unlike traditional forces in Kham, Jagö Topden had a relatively clear understanding of the general political situation of the time, and he appropriated new ideas for reforms. He formed alliances with various forces that contended for control of the region and adopted the regional identity of a united Kham. Ultimately, he emerged as the dominant figure to compete with the Dergé king.
\end{abstract}

Keywords: Jagö Topden, nationalism, Xikang, new elite, political strongmen, Dergé

\section{Introduction}

In the late nineteenth and early twentieth centuries, Kham polities were undergoing a period of upheaval and radical changes due to both exogenous and endogenous factors. The disruption fostered growing contention over the control of polities in Kham, a buffer zone between the larger political entities of Central Tibet and Qing China as well as an in-between area. As I have argued elsewhere (Tsomu 2015, 1), this

Gros, Stéphane (ed.), Frontier Tibet: Patterns of Change in the Sino-Tibetan Borderlands. Amsterdam, Amsterdam University Press 2019

DOI: 10.5117/9789463728713_CH11 
made Kham a contingent region, with a host of political, cultural, and economic complexities. ${ }^{1}$ During this period, the Kham region became a zone of contestation, resulting from the growing assertion of power and authority by both Qing and Nationalist China and the attempt to check the Chinese penetration by the Tibetan government (the Ganden Phodrang). The situation created political flux where belongings and allegiances of various polities in Kham were put to the test (Gros 2016, 209).

The struggle for authority was also endogenous, in that this period also saw a newly emergent elite that sought to wrest power from traditional hegemonic hereditary ruling families, i.e. families of the local gyelpo (king), depa (governor), or pönpo (chief), or from monasteries represented by religious leaders such as reincarnated lamas or khenpos (abbots). Part of this new group of leaders, the so-called 'modern educated elite'2 that had received a modern education, was well represented by Kelzang Tsering, the well-known Khampa official working in the Nationalist government. By climbing Kham society's traditional hierarchy thanks to their modern education, this elite group achieved upward social mobility and turned its attention toward a wider national stage and social changes. ${ }^{3}$ The new elite also included Khampa trader families such as the Pangdatsang in Markham, located in western Kham, west of the Drichu River (Ch. Jinshajiang). After having become part of a modern middle class that

1 I examine the geo-political situation of Kham at length in my book The Rise of Gönpo Namgyel in Kham: The Blind Warrior of Nyarong (2015).

2 I refer to the emergent elite in Batang as modern because they were different from the traditional elite in that they had received a modern education and had ventured beyond the traditional cultural milieu. This elite formed a close alliance with the Nationalists. Within less than five years, from November 1907 to June 1911, during gaitu guiliu (the policy of 'substituting chieftains with state appointed civilian officials'), over 200 schools were opened in the Sichuan borderlands. However, after the collapse of the Qing dynasty in 1912, except for schools in Luding (Chakzamkha), Kangding (Dartsedo), and Bathang, most of them stopped recruiting students. For details about the impact of modern education in Kham, refer to Zhang Jingxi (1939, 1-85); Wang Di (1986, 55-62); Lin Junhua (1993, 39-46, 17); Liu Xianqiang (2007, 90-95; 2008); Ma Tinzhong (2008, 68-74; 2012, 205-209); Xue Jiangang (2013, 1-54).

3 As officials in the Nationalist government, Kelzang Tsering and other Khampa elites who had received a 'modern education' were deeply influenced by ideals of social and political modernization. Their political ambition had also shifted beyond narrow local perspectives, and they were influential in shaping the Nationalist government's Tibet policies. They were also instrumental in initiating the 'Khampa rule of Kham' movement, which targeted the Sichuan warlord and encroachments on Kham by Central Tibetan troops. For details about the movement, see Peng Wenbin (2002, 57-84); You Zhen (2010, 104-108); Wang Juan (2013, 25-30); Luo Shaoming $(2015,1-5)$. 
had emerged in Lhasa, the Pangdatsang also began to become actively involved in local Kham politics and larger politics regarding Sino-Tibetan relations since the 1930 s. $^{4}$

In addition, former headmen, such as Jagö Topden in Dergé - a powerful kingdom in northern Kham - and others subordinate to aforementioned hegemonic traditional rulers such as gyelpo, pönpo, and depa rose to become dominant rulers in various regions of Kham. Some of these new authority figures replaced traditional hegemonic rulers. ${ }^{5}$ In contemporary sources these new political actors are referred to as jöntang chenpo, which literally means 'men of ability'. ${ }^{6}$ A man of ability is a term generally applied to a person capable of achieving success. However, in the case of Jagö, describing him simply as 'an able man' does not do him justice. He could be considered a 'great man', but the Tibetan term mi chenpo (literally meaning 'a person with high rank/status', i.e. great man) is usually equated with hereditary hegemonic rulers or people of noble birth. One of the secondary Tibetan sources describes Jagö Topden as a khadrak wangshechen, which literally means 'a person who is domineering/dictatorial' in Kham (Lodrö Püntsok 1994, 191). I consider that the indigenous term used to refer to Jagö comes very close to the English term 'strongman'. Thus, I will refer to these new political actors as 'strongmen', a coinage that also emphasizes that they are not from traditional hereditary families and constituted a newly emerging category of leaders in Kham politics. These 'strongmen' came to the fore in Kham politics by adapting to and negotiating with the broader political milieu. With initial support from a small coterie of like-minded followers, these men drew on their strong character, personal ambition, charisma, and ability to negotiate and 'collaborate' with power holders at

4 For the rise of the family and its role in the politics of Kham and Central Tibet, refer to Goldstein (1989, 180); McGranahan (2005, 253-274); Zhang Faxian (2011, 25-30, 138); Meilang Zongzhen [Mönlam Tsöndrü] (2005a, 15-21; 2005b, 50-55; 2009, 71-80); Tsomu (2016, 177-210); Galli, this volume.

5 After the collapse of Qing rule in 1912, except for a few low-ranking commanding Officers (zhangguan si) who restored their rule over remote areas in Lithang and Nyachukha (Yajiang), the Bathang and Lithang depas were unable to restore their authority; see Wu Fengpei $(1984,195)$. In southern Kham, in particular Chaktreng and Dabpa regions that used to be under Bathang and Lithang depas (governors), new political actors came to the fore after the collapse of Qing rule in 1912. These groups, consisting of former headmen who were subordinate to the traditional rulers, rose to fill the power vacuum after the traditional rulers were unable to restore their power.

6 For example, Jagö Topden is described as 'wise in political decision-making' (chapsi kyi chawar khedzang denpa) in Lodrö Püntsok et al. $(1995,191)$. Furthermore, Püntsok Wangyel portrays Jagö as namrik denpa, literally meaning 'the wise'; see Chung Tsering $(2006,83)$. 
different levels to build their power. Like certain former headmen, these strongmen distinguished themselves by their outstanding leadership and bravery in predatory raids against neighbouring areas and/or sometimes in military exploits against Nationalist troops stationed in local regions. Consequently, they emerged as the new ruling elite. ${ }^{7}$ Here it might be worthwhile comparing the local strongmen represented by Jagö Topden in Dergé in 1900 s with another strongman - Nyarong Gönpo Namgyel, who rose to become a dominant power in Nyarong and Kham in the mid-nineteenth century. These two shared similar traits - such as being strong-willed, very ambitious, charismatic, and capable of taking advantage of popular sentiment and of establishing a collaboration network with various forces. However, the latter rose to power under very different circumstances. At the time of the Gönpo Namgyel's ascendancy (1836-1865), external forces such as Qing China and Central Tibet were powerful but distant centers. In most cases, their control of various Kham polities was nominal, weak, and indirect. ${ }^{8}$ Affairs in Kham and those in various Kham polities were determined by the local context. This included Kham's social-political milieu, the local structure of authority, the local political culture - kinship loyalty, regional allegiance, moral and political commitments, worldview, as well as culturally specific values and beliefs such as machismo, honor, and revenge. ${ }^{9}$

This chapter examines the way political authority shifted in Kham in the early twentieth century through the case study of the rise of Jagö Topden, a charismatic headman who successfully challenged the power of the Dergé king in the early part of the twentieth century. The case of Jagö Topden is particularly revealing about Kham as a political territory and the shifting nature of authority and the growing legitimacy of Kham in the late nineteenth and early twentieth centuries. The situation in the 1920 , at the start of Jagö's ascendancy, was unlike the aforementioned circumstances in which Gönpo Namgyel ascended to power. In this later period, Kham found itself at the center of growing competition over its control between the Tibetan government in Lhasa, the Chinese Nationalist government, the Chinese warlord Liu Wenhui, and the Khampa elite that was striving for the 'Khampa rule of Kham' (Tib. Kangpé rangsi rangkyong

7 For details about these self-made strongmen in Chaktreng and Dabpa counties, refer to van Spengen (2002, 7-29); Qin Heping (2007, 1-9); Wang Haibing (2013, 69-74).

8 One exception to the general situation is the Qing control in Batang. For details, refer to Coleman (2014).

9 For details, refer to Tsomu $(2015,81-118)$. 
or Kangpé rangdé rangpön; Ch. Kangren zhi Kang). Thus, as a new emergent strongman with ambition, it was imperative for Jagö to strategize and operate not only in the confines of Dergé court politics but also to be cognizant of the broader politics of the Kham region, Central Tibet, and China. This case study shows the agency of the local elite in responding to the Chinese government's efforts to incorporate the contested Kham region as an inalienable part of Chinese national space. In doing so, it reveals the complicated interactions between local Chinese authorities and local society in the process of establishing a nation state in modern Chinese history.

This case study also demonstrates how the nature of authority based on traditional hereditary and ascribed status began to shift to the recognition of achieved status. In addition to the external forces discussed above, the challenge to traditional authority also came from indigenous strongmen and their reliance on personal charisma, ability, and ambition, as typified by Jagö. The latter's ascendancy resulted from the weakening of the Dergé king's power and authority due to increasing control by the Qing administration (following the gaitu guiliu policy) since 1909, and by the direct rule of a commander sent by the Central Tibetan government in 1918 following its military intervention. Through his personal ambition and political skills of aptly mediating and collaborating with various forces he rose to become an alternative focus of power in the 1930s and started to increasingly usurp the power and authority of the royal family following the death of the Dergé king, Tsewang Düdül (1916-1942). For the purpose of this chapter, I will first briefly introduce the Dergé polity and provide an overview of the court politics and decline of the Dergé royal family. Next, I will focus on how Jagö Topden gradually rose to prominence in Kham where there was constant strife and describe how he eventually became a dominant local force who was on a par with the Dergé king. Through his upbringing and education among children of aristocratic families in Lhasa, Jagö became familiar with the workings of the Lhasa government and with some Tibetan officials. Furthermore, his studies at the 'Institute of Public Security and Administration of Xikang' (Xikang bao'an xingzheng jiangxihui) run by Liu Wenhui in Dartsedo helped him not only to understand the Nationalist ideology and the working of the Chinese administration of Kham but also to embrace new ideas. All this experience forged his cosmopolitan view of the world and enabled him to have the upper hand. Astute and resourceful, Jagö took full advantage of various opportunities to establish formal and informal alliances with various forces as a means of extending his own power and authority. 


\section{The Authority of the 'Dergé Kingdom' and Its Decline}

\section{The Political Structure and Authority in Dergé}

Before any discussion can take place about the political competition that ensued in the late nineteenth and early twentieth centuries, a brief outline of the structure of the political system in Dergé needs to be given. Located in the river basin of the Upper Yangtze in northwestern Kham, the Dergé kingdom was believed to be the most densely populated area and the 'richest agricultural and manufacturing district of eastern Tibet' (Rockhill 1891, 227) (see Map 11.1). In the mid-eighteenth century, when Dergé was ruled by king Lodrö Püntsok, there were 25 districts with a total of 33 local chiefs/headmen (dzong go) and 43 nomadic tribes. ${ }^{10}$ Dergé could be described as a feudal state with a decentralized bureaucracy formed by a system in which land was granted to hereditary officials in exchange for administrative responsibilities.

Although the personalities and management methods might have changed during different periods, the core principle of the right of hereditary ruler remained constant. The highest levels of bureaucracy consisted of 200 aristocrats. Each of the four larger designated districts - Yilhung in the east, Garjé in the south, Drongpa in the west, and Sershül in the north - had a chief or head official/minister (nyerchen, literally 'the chief steward') who was selected from families of aristocratic retinue appointees (dünkörkhak/dünkör). These officials served on the highest secular political body in the king's court known as the Council of Ministers and Stewards (nyerchak lhengyekang). They were known as pöngozhi (four chief officials) or pönchenzhi (four great officials) (Tubten Püntsok 2010, 78). Together with the treasurer (chakdzö), secretary (drungyik), and chamberlain (zimpön), they formed the first rank of officials and resided mostly in the capital itself (Lhalung Chimé Dörjé and Dayang 2009, 49-50; Tubten Püntsok 2010, 78).

The second level of officials consisted of 33 local chiefs/headmen (dzong go) that headed the 25 districts (dzongkhak or dechok), who were also selected from among aristocratic retinue appointees and were mostly hereditary. ${ }^{11}$

10 Its domain included present-day Dergé, Pelyül, Sershül, and Jomda counties as well as the western part of Kandzé County.

11 Among the 33 local chiefs, four 'outer officials' (chipöngo) from four leading families retained power during most of Dergé's history. These four 'outer officials' were from Gamongna, Sokmotsang, Nyakshik Setsa, and Gojo Samdrup. These four officials were responsible for providing soldiers to protect Dergé borders when necessary. See Karma Gyeltsen (1994, 78-79). However, Tubten Püntsok calls them pöngosum; he also holds that Gamongna Sokmotsang should be one instead of two as listed in Karma Gyeltsen. See Tubten Püntsok (2010, 8o). 


\section{Map 11.1 Dergé at the Time of Jagö Topden}

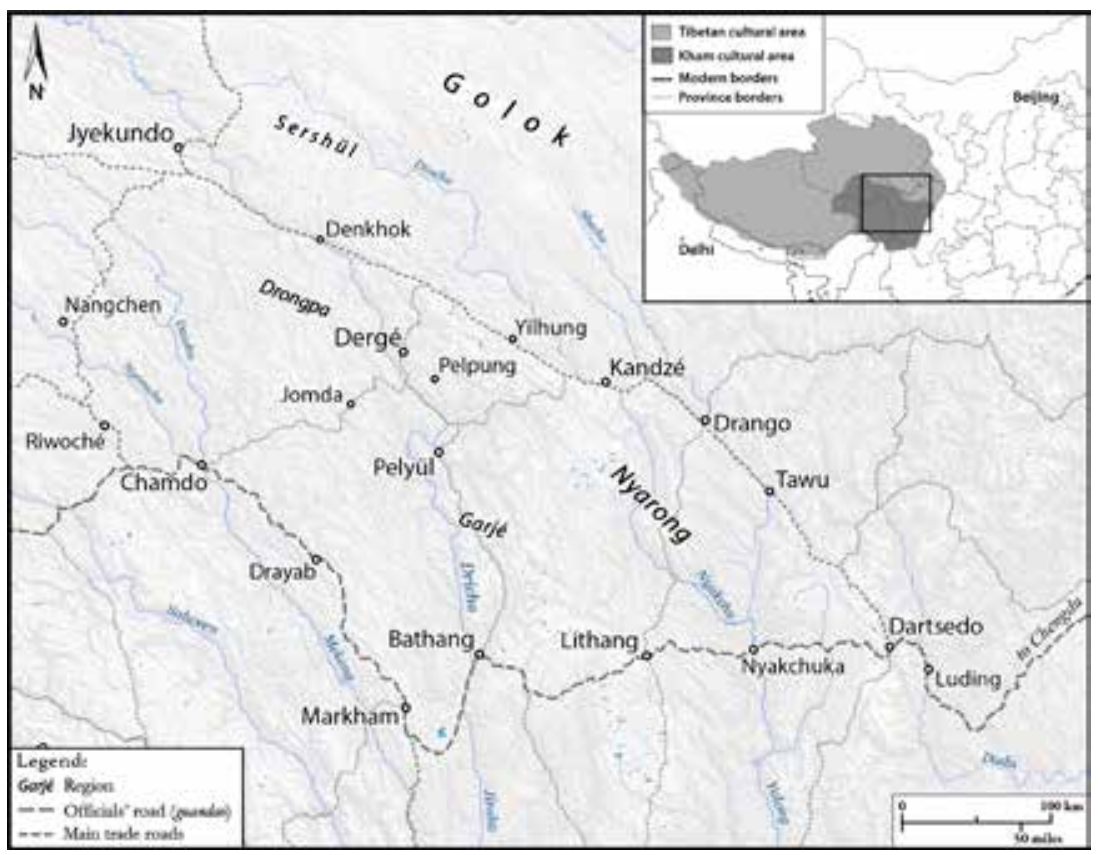

Sources: Based on SRTM (NASA) and modern administrative borders extracted from GADM database (www.gadm.org, v.2.5 July 2015)

Author: Rémi Chaix

The second strata of officials also included another 41 aristocratic retinue appointees. ${ }^{12}$

Lastly, the third rank of officials consisted of 8 o local representatives or village headmen (hördra), who functioned as the king's representatives or deputies responsible for administering corvée labour (ulak). ${ }^{13}$ Under the local representatives, there were leaders ( $\mathrm{gopa}$ ) who did not have an official rank. These leaders were chosen from among the common people to assist the local representative in collecting taxes, administering labour services, and requisitions. The first two ranks of officials were required to perform administrative services in Dergé's central government in exchange for the land granted to them by the king. However, except for the first rank of officials, most hereditary chiefs were not required to reside in the capital.

12 Tubten Püntsok states that there are 43 aristocratic retinues. For a detailed list, refer to Tubten Püntsok (2010, 86-89).

13 Tubten Püntsok lists 88 hördra. For details, see Tubten Püntsok (2010, 90-93). 
Thus, it was likely that chief officials/ministers (nyerchen), local chiefs (dzong go), or aristocratic retinue appointees (dünkörkhak) in Dergé set themselves up as territorial rulers on their own estates and became excessively powerful. Consequently, these hereditary chiefs and aristocratic retinue appointees maintained a high degree of local autonomy. The division of land among hereditary local chiefs resulted in alternative foci of power that could counter the authority of the king. This would make the king primus inter pares, if local districts became exceptionally powerful or allied with one another (Hartley 1997, 25).

The political system of the Dergé Kingdom is commonly portrayed as 'the alliance between secular and religious powers' to differentiate it from 'the merging of religion and politics' (Tib. chösi zungdrel; Ch. zhengjiao heyi), by later Chinese researchers (Du Yongbin 1989, 85-99; Zeng Wenqiong $1988,17-25)$. The royal family of Dergé, through close alliance with monastic hierarchs, assumed secular power and had religious power in its service. To balance the power of local hereditary chiefs, the kings accommodated and patronized monasteries of different traditions (Hartley 1997, 30, 38). Until the early nineteenth century, the king of Dergé usually served as the abbot of Lhundrupteng monastery, commonly known as Dergé Gönchen, which belonged to the Sakya school of Tibetan Buddhism. Yet, the royal family also kept close ties with chaplains (üla) from five head monasteries (ügön) that belonged to Nyingma and Kagyü traditions.

\section{The Decline of the Power and Authority of the Dergé King's Family}

Dergé had flourished as a cultural center with the patronage of the Dergé royal family and the Manchu court. In the late eighteenth century, the power and authority of the Dergé kingdom began to wane. The chief reason for its decline is worthy of a Shakespearian drama. The main source of discord involved rivalry for the throne within the royal family as well as competition for power between the king and his subordinate headmen. In 1790, as the Dergé prince Tsewang Dörjé Rikdzin (1786-1847) was still young, his mother, the dowager queen Tsewang Lhamo served as the regent (Ronis 2011, 61-81; Tubten Püntsok 2010, 50). During her reign (1790-1806/1808), ${ }^{14}$ Dergé battled with its northern neighbour Lingtsang, and the queen's rule was challenged by a number of lamas and aristocrats who were highly displeased with her. Eventually, war with the Kharnang tribe in Dzatö in 1808 forced her to leave

14 Though her son was enthroned in 1798, she ruled as before until 1806. See Tubten Püntsok $(2010,51)$. 
the capital (Tsewang Dörjé Rikdzin 1989, 100-101; Ronis 2011, 61-81). ${ }^{15}$ The king, who later authored The Genealogy of the Dergé Kings, ${ }^{16}$ was said to have taken no interest in governing, preferring instead to devote his time to religion by becoming a fully ordained monk in 1826 (Tubten Püntsok 2010, 52). ${ }^{17}$ The combination of internal strife and a disinterested king naturally undermined the power and authority of the kingdom. The situation barely improved during the reign of the eighteenth king, Damtsik Dörjé (1811-1853), from 1847 to 1853 . This weak king was unable to restore the authority of the royal family.

While internecine strife undoubtedly undermined the royal family's ability to assert control over the region, the situation was further aggravated by the emergence of Nyarong chief Gönpo Namgyel as the key figure on Kham's local political scene in the nineteenth century. ${ }^{18}$ Gönpo Namgyel's occupation of Dergé ${ }^{19}$ in the mid-nineteenth century forced the Dergé king, Chimé Tapei Dörjé (1840-1896), to seek military assistance from both the Qing and Lhasa authorities (Tsomu 2015, 169-172). However, help from Lhasa did not come without a price. Having defeated Gönpo Namgyel, Lhasa began to exert a certain degree of authority over the northern Kham region - including Dergé via the Tibetan High Commissioner's Office in Nyarong (Nyarong Chikhyap) in 1865-1866. Thereafter, the Dergé king's family forged a closer relationship with Lhasa authorities and the latter began to exert growing influence in Dergé. ${ }^{20}$

15 Dege xianzhi explicitly mentions that resentment towards the mother was caused by her impropriety in her private life and by unduly trusting the monks of Dzokchen monastery. It also recounts that in 1799, when the headmen failed to persuade the king's mother to return the political power to her son, they successfully mobilized armed forces to oust the royal mother and to crown the young thirteen-year-old king. However, as Jann Ronis (2011) convincingly argues, this was in fact a misreading of a passage in the Royal Genealogies about a ceremony for the crown prince, Tsewang Dorjé Rikdzin, which was performed in 1798. The Genealogy of the Dergé Kings written by the king himself clearly states that he did not take over the government until 1806 or 1808 . See Sichuan sheng Dege xianzhi bianzuan weiyuanhui $(1995,445)$.

16 The king wrote the work in 1828 , and its full title in Tibetan is Dpal sa skyong Sde dge chos kyi rgyal po rim byon gyi rnam thar dge legs nor bu'i phreng ba 'dod dgu rab 'phel bya ba.

17 In 1826 in the presence of Ngör khenchen Jampa Kunga Tendzin, he took the gelong (bhiksu, fully ordained with 253 precepts) vow and became a fully ordained monk. When the king was ordained, he was given the name Jampa Künga Sanggyé Tenpai Gyeltsen. He was considered to be a great scholar well versed in the teachings of Ngör sub-school of the Sakya school. See Tubten Püntsok $\left(2010,5^{2}\right)$.

18 For a more detailed study of the rise of Gönpo Namgyel, refer to Tsomu (2015).

19 At the time Dergé was ruled by its nineteenth king, Chimé Takpé Dörjé, who was only nine years old in 186o. To prevent the whole Dergé region from revolting against his rule, Gönpo Namgyel took the king, his mother, and local revered lamas as hostages to Nyarong. See Yelé Tsültrim (n.d., 26); Kongtrül Yönten Gyatso and Karma Trinlé (1997, 293).

20 For details about the authority of the Tibetan commissioner over Dergé, see Tsomu (2015, 224-26). 
By the 1870 , competition for power and authority between the Dergé king and his subordinate headmen - a common recurring theme in the history of Dergé since the late eighteenth century - reemerged. In particular, a weak king gave local chiefs (dzong go) ample opportunity to become foci of power to contest his authority. The intensification of internal unrest resulted from resentment on the part of the king's 30 chiefs (dzong go) toward the king for handing over a follower to the amban during their pilgrimage to Central Tibet in 1871. The follower was accused of killing a Chinese member of staff under the amban's responsibility; eventually he was executed by the latter. The king's action was probably interpreted as an act of cowardice and weakness. The event deepened the rift between the king and his subordinate chiefs. By the late 1870 , all 30 chiefs were believed to have increasingly defied the king (Ge Le 1984, 259; Sichuan sheng Dege xianzhi bianzuan weiyuanhui 1995, 471).

Furthermore, in the 1890 s, amidst the intense competition for power between the king and his subordinate headmen, great discord arose between King Chimé Tapei Dörjé and Queen Tseten Drölkar from the aristocratic family known as Ragashak in Lhasa, which led to an intense struggle between the king's two sons for succession to the throne. This plunged Dergé into factional politics which lasted until the 1940s. The two factions associated with the Dergé brothers - Dörjé Senggé (commonly known as Aja), who succeeded his father and his brother Ngawang Jampel Rinchen (commonly known as Baba), who received support from the queen - resorted time after time to their old strategies of seeking assistance and support from either successive Sichuan or Lhasa authorities. ${ }^{21}$ Late Qing Sichuan authorities and the Ganden Phodrang under the Thirteenth Dalai Lama had both launched projects to strengthen their control and authority in Kham. Both also actively participated in the succession struggles and attempted to settle their favored candidate on the throne (Lu Chuanlin 2001a, 467-470; 2001b, 474-479). ${ }^{22}$ In the end, with the support of General Zhao Erfeng, Dörjé Senggé was able to

21 For details about the Chinese official Zhang Ji's attempt to replace the Dergé king and his headmen with government-appointed officials by taking the king, the queen, and their two children to Chengdu, see Tubten Püntsok (2010, 56-57); Lodrö Püntsok (1994, 79-8o).

22 It is interesting to note that the Lhasa authorities seemed to have supported both candidates at one point or another, depending on their interests at a particular time. With the support of the Tibetan government, the two brothers were able to return to Dergé in 1897 after their parents had passed away in Chengdu in the previous year. The Tibetan government had Dörjé Senggé succeed to the Dergé throne. They also had him married to Sönam Tsomo, the daughter of an aristocratic family known as Nangsotsang from the Penpo area near Lhasa. See Tubten Püntsok $(2010,57)$. For instance, though the Tibetan troops stationed in Nyarong dispatched representatives and cavalry to Dergé in 1906 to support Ngawang's claim to the throne, the 
force his brother Ngawang and his followers to flee to Golok (Zhao Erfeng 2001, 504-505). Later, they followed the Thirteenth Dalai Lama to Central Tibet (Karma Gyeltsen 1994, 61; Ge Le 1984, 262; Baima Dengdeng and Xiake Zelang 2008, 189), where Ngawang was granted the title of theji of third rank ${ }^{23}$ and became an official of the Ganden Phodrang (Baima Dengdeng and Xiake Zelang 2008, 189; Sichuan sheng Dege xianzhi bianzuan weiyuanhui 1995, 472).

Meanwhile, when the Dergé kingdom underwent gaitu guiliu (the policy of 'substituting chieftains with state-appointed civilian officials') in 1909, Dörjé Senggé was granted the hereditary civilian position of $d u s i$ (commander) and took up residence in Bathang (Sichuan sheng Dege xianzhi bianzuan weiyuanhui 1995, 446). ${ }^{24}$ When the Qing collapsed in 1912, many indigenous kings, chieftains, and headmen in the Kham borderland re-established their rule at the time, with Dörjé Senggé also returning to Dergé. Chinese officials in Dergé continued to rely on Dörjé's authority to preside over the common people and the headmen in Dergé. He was given official titles such as 'the battalion commander of indigenous soldiers' (tubing yingzhang) and 'the commissioner in charge of the corvée labour and grain tax' (chailiang zongban) (Ren Naiqiang 2009, 186-187). In 1918 when Tibetan troops invaded Kham, they occupied Dergé. At that time, the Lhasa government escorted Dörjé Senggé and his wife to Central Tibet, placing them under house arrest (Ren Naiqiang 2009, 187; Sichuan sheng Dege xianzhi bianzuan weiyuanhui 1995, 16). Dörjé Senggé passed away in 1919 in Central Tibet, leaving a son and three daughters (Lodrö Püntsok 1994, 86; Tubten Püntsok 2010, 62; Lhalung Chimé Dörjé and Dayang 2009, 182).

\section{Jagö Topden's Rise to Power}

As we have seen, from the end of the nineteenth to the early twentieth century, the Dergé royal family was caught up in rivalry over the administration

Lhasa authorities also supported his brother Dörjé Senggé in fighting against Jampel. See Ma Guangwen (1990, 493-497); Sichuan sheng Dege xianzhi bianzuan weiyuanhui (1995, 472).

23 Theji was originally a Mongol title that referred to a prince and was similar to the Chinese term taizi (crown prince). It later became an official title with the third rank within the Tibetan government. The relevant accounts in Chinese about the title granted to Ngawang maintains he received the title of theji with the fourth rank, which seems to be based on oral sources and is because these authors do not know that the official with the title theji is the one with the third rank with the Tibetan government. Interestingly, Tubten Püntsok $(2010,60)$ simply states that Ngawang was given the official position with the fifth rank, without specifying the actual title. 24 His annual salary was 3000 taels of silver. See Sichuan sheng Dege xianzhi bianzuan weiyuanhui $(1995,446)$. 
of the kingdom. This resulted in decades of social unrest amidst growing contention for the control of Kham between the Ganden Phodrang and the Qing court as well as the successive Chinese regimes. It also created a conflict of interest among the elite and provided an opportunity for ambitious local figures to become alternative foci of power, usurping the power and authority of the royal family. One such figure was Jagö Topden, one of the Dergé dünkör (aristocratic retinue appointees).

\section{Jagö Topden's Family Background}

Jagö Topden was born in Hakhok in Dergé in 1901. His family had been very much involved in the internal wrangling within the Dergé royal family throughout the late nineteenth and early twentieth centuries. His grandfather, Jagö Pema Ledrup, served as chief steward at the Dergé king's court. ${ }^{25}$ Later, his father, Jagö Tashi Namgyel, inherited the position of the chief minister of Dergé and championed the cause of the younger Dergé brother, Ngawang. He was believed to have been poisoned by the faction supporting the elder Dergé brother, Dörjé Senggé, in 1906-1907 (Lodrö Püntsok 1994, 189; Lhalung Chimé Dörjé and Dayang 2009, 179; Tubten Püntsok, 2010, 58). Since Jagö Topden and his older brother Jagö Tsenam were too young to be chief minister of Dergé, his mother Tsewang Drölma inherited her husband's position and continued to be loyal to Ngawang's faction. ${ }^{26}$ Having been defeated by Dörjé Senggé's faction and the Qing troops under Zhao Erfeng in April 1909 (Zhao Erfeng 2001, 504; Sichuan sheng Dege xianzhi bianzuan weiyuanhui 1995, 14-15; Baima Dengdeng and Xiake Zelang 2008, 189), Tsewang Drölma, together with all her children, followed Ngawang and the Thirteenth Dalai Lama to Lhasa. They first settled in the Nakchu region in northern Tibet (Ge Le 1984, 262; Karma Gyeltsen 1994, 61; Baima Dengdeng and Xiake Zelang 2008, 189). As stated above, while Ngawang was granted the title of theji, the head of the Jagö family was appointed gopa (headman) of Janggyap in Nakchu region. Thereupon,

25 Pema Ledrup, known to be brave and resourceful, gained the king's trust for having rescued the king from Nyarong in the 1860 s. According to oral traditions, as he had directly intervened in the regent mother Chöying Zangmo's illicit affair with a subordinate headman, it was believed that the regent had poisoned him. For details about Jagö Pema Ledrup's role in bringing down Gönpo Namgyel and rescuing the king, see Tsomu $(2015,187,215)$.

26 Jagö Topden's mother was considered to be one of the three most powerful women during the period, popularly known as 'three demonesses of Kham'. The other two were the seventh chief of Khangsar Yangchen Khendro (also known as Khangsar Yangchen Drölma) and Gyari Chimé Drölma of Upper Nyarong. For details, refer to Tsomu (2018). 
they all became part of the Ganden Phodrang. ${ }^{27}$ In 1910-1911, Ngawang and his subordinates assisted the Lhasa troops to fight against the Qing troops in Gyantsé. Their bravery and outstanding performance in the fight against the Qing troops established their reputation and earned them recognition from the Thirteenth Dalai Lama. The Dalai Lama granted estates (zhika) to the Jagö and Drebö families near Sera monastery in Lhasa and near Yardrok Yumtso in Tsang, respectively. He also assigned over a dozen khölpa families to each of the two families (Baima Dengdeng and Xiake Zelang 2008, 191; Lhalung Chimé Dörjé and Dayang 2009, 179-180; Lodrö Püntsok 1994, 190).

The Jagö family's goal of restoring their authority in their home region in Dergé coincided with the period when the Lhasa government under the Thirteenth Dalai Lama was engaged in nation-building projects to extend their control and to strengthen their authority in Kham. With new-found patronage from the Dalai Lama, Tsewang Drölma made a great effort to restore her family's power and authority in Dergé. In 1918 when the Ganden Phodrang army seized Chamdo, at Tsewang Drölma's request the Thirteenth Dalai Lama wrote to Kalön Lama Jampa Tendar, Kham's high commissioner (Domé chikhyap), whose office was first established in 1913 (Tu Ga 2009, 164), demanding that Tibetan troops restore power to the Jagö family in Dergé and exempt the family from all corvée labour and taxes. Fearing the threat posed by Dörjé Senggé's faction, the Jagö family temporarily settled in Wangpotö to the west of the Drichu River. To ensure that her sons Jagö Tsenam and Jagö Topden would receive the best education, she took the farsighted action of sending them to Tsé Lopdra, a school that prepared the Lhasa aristocracy for service in the Ganden Phodrang. This training, which Jagö Topden completed within three years with excellent results, enabled him not only to become familiar with the Tibetan government's affairs and the situation in Central Tibet but also to become acquainted with future Ganden Phodrang officials (Lodrö Püntsok 1994, 190; Lai Zuozhong 1996, 97; Baima Dengdeng and Xiake Zelang 2008, 192; Lhalung Chimé Dörjé and Dayang 2009, 181). What happened later proves that this training was very useful for the Jagö family's restoration of their power and authority in Dergé (Lhalung Chimé Dörjé and Dayang 2009, 181; Baima Dengdeng and Xiake Zelang, 2008, 192; Lai Ziozhong 1996, 97). Since 1918, Lhasa troops had been occupying areas such as Dergé, Pelyül, Sershül, and Jomda - all

27 Having first fled to Golok, following a recommendation from Jamyang Zhepa, the head lama reincarnate of Labrang Trashikhyil, they sought refuge with warlords in Qinghai and temporarily settled in Tsolho (Ch. Hainan). With the assistance of Jamyang Zhepa, they followed the Thirteenth Dalai Lama to Central Tibet. 
under the rule of the Dergé king (Sichuan sheng Dege xianzhi bianzuan weiyuanhui 1995, 445-446; Baima Dengdeng and Xiake Zelang 2008, 192). By 1921, when Jagö Topden returned to Dergé as a headman, he became a useful ally for the Ganden Phodrang. In addition, his familiarity with Lhasa nobles and the Ganden Phodrang's strategies provided him with a secure footing in dealing with Lhasa and in his effort to restore his family's power and authority in Dergé. In 1926 Dörjé Senggé's son Tsewang Düdül (1916-1942) was authorized by Domé chikhyap to rule Dergé (Tubten Püntsok 2010, 62; Lodrö Püntsok 1994, 86). ${ }^{28}$ But military and political power was still controlled by the Dergé Commissioner's Office (Dergé chikhyap) that had been set up in 1918 and was headed by the dapön (the regimental commander) of Tibetan troops in Dergé. ${ }^{29}$ To restore his family's power, Jagö had to do his best to gain the support of the dapön of Lhasa troops stationed in Dergé. As Jagö was unable to forge a good relationship with regimental commander Chungrangpa, a Lhasa aristocrat, he had to settle for the position of minor headman (a common dünkör) (Lodrö Püntsok 1994, 190; Dengdeng and Xiake Zelang, 2008, 192; Lhalung Chimé Dörjé and Dayang 2009, 182). $3^{0}$

\section{The Gradual Rise of the Jagö Family}

Jagö's fortune changed when Khemé became regimental commander in 1929. They were old acquaintances from Lhasa, and Khemé entrusted Jagö with handling some important matters in Sershül and Pelyül. Jagö was not only shrewd, capable, and experienced, but also decisive in handling affairs; hence, he was able to win Khemé's trust. Around 1930, he was eventually

28 Tubten Püntsok $(2010,63)$ states that in 1919 the young king was enthroned by Domé chikhyap. Since he was only four years old, Situ rinpoché Pema Wangchok of Pelpung monastery served as regent. Furthermore, in 1926 the Thirteenth Dalai Lama's decree of enthroning Tsewang Düdül was shown at the assembly attended by the regiment commander of Tibetan troops stationed in Dergé, the king and all the officials under the king. This is probably the reason that the Gazetteer of Dergé (16) maintains that Tsewang was chosen to accede to the Dergé throne by the Thirteenth Dalai Lama in 1926.

29 According to an oral source, Dergé King Tsewang Düdül and others could only have had rather low living expenses, and even the 'tribute' paid by the various major and minor headmen all belonged to the Tibetan troops. See Lhalung Chimé Dörjé and Dayang $(2009,182)$.

30 At the time ministers in charge of the Office of Ministers and Stewards included Nyerchen Gyangkhang rinpoché, Hörcho Peldo, headman of Tsari called Tsari Nyergé, the Great Chamdzö Namsé Tsega, the Minor Chamdzö Wokma Sonam Tsering, and others. Later, the Great Chamdzö Namsé Tsega was removed from office for accepting bribes in Jomda. Wokma Sonam Tsering was promoted to Great Chakdzö. See Lhalung Chimé Dörjé and Dayang $(2009,182)$; Baima Dengdeng and Xiake Zelang $(2008,192)$. 
appointed chief minister (nyerchen) of the Dergé royal court under King Tsewang Düdül. With this appointment, Jagö had accomplished the first step of restoring his family's power in Dergé. He was said to be courageous, insightful, very eloquent, and good at socializing with all kinds of people. Jagö now positioned himself in the inner circle of the Dergé court and gradually consolidated his power.

Jagö also made great efforts to gain the trust of King Tsewang Düdül after the latter had regained control of Dergé in 1932. The Dergé royal family regained some stability with the support of the Ganden Phodrang. However, the Ganden Phodrang's position in regions east of the Drichu River had not been completely secured; hence, there was constant fighting between Lhasa and Chinese troops. In 1932 the two parties reached what became known as the 'Kamtok Agreement' (Kamtok dröchö/Kamtok dröching). According to this agreement Lhasa consented to withdraw its troops from the regions east of the Drichu River. ${ }^{31}$ Jagö managed to gain the king's trust, and he in turn appeared to be loyal to the king. He led forces to suppress the rebellion against the Dergé king by headmen from Hörpo and other areas in Pelyül (Sichuan sheng Dege xianzhi bianzuan weiyuanhui 1995, 19; Lai Zuozhong 1996, 98).

Although the Lhasa government had withdrawn its troops from the Kham region, including Dergé, it continued to seek to levy grain taxes from Jomda, the regions to the west of the Drichu River that remained under the Dergé king's authority. As Jagö began to mobilize the local populace against the Ganden Phodrang's authority (Lodrö Püntsok 1994, 191; Lai Zuozhong 1996, 98; Lhalung Chimé Dörjé and Dayang 2009, 179; Chengdu junqu silingbu 1957, 6), the people of Dergé recognized him as an able and loyal minister of the Dergé court..$^{22}$ The king also came to be dependent on him to carry out many of the affairs of the court.

The aforementioned actions show that Jagö was fully aware that his own position in Dergé at that time depended on the king's patronage. In the meantime, Jagö also fully understood that he would not be able to

31 At that time Tsewang Düdül was seventeen years old and was appointed to positions such as Supervising Official in Charge of the Militia Affairs of the Five Counties including Dergé, Pelyül, Denkhok, Sershül and Battalion Commander of the Indigenous Troops by the Dergé County government under Liu Wenhui's control. Like any other government-appointed official, he was given a monthly salary. Jagö Topden and others also arranged to have Tsewang Düdül take the daughter of the Nangchen king named Jamyang Pelmo as his wife.

32 Many years later, in 1945 or 1946, he also incited the local people in Jomda to the west of the Drichu River to refuse to pay grain taxes to the Lhasa government. See Lai Zuozhong (1996, 98) and Chengdu junqu silingbu $(1957,6)$. 
totally secure his position in the king's court without a strong power base in Dergé itself - especially when key subordinate headmen under the Dergé king were competing for the position of head of the Office of Ministers and Stewards in Dergé. To further consolidate and expand his power base, like many other elites in Kham, Jagö resorted to the common strategy of forming matrimonial alliances. In 1933, he married Sönam Chömtso, the daughter of the Lhari chief Kelzang Püntsok in Yilhung, who was powerful and ruled over 1000 households (Lai Zuozhong 1996, 98; Baima Dengdeng and Xiake Zelang 2008, 192-193; Lhalung Chimé Dörjé and Dayang 2009, 183; Lodrö Püntsok 1994, 151-152).33 After the Lhari chief's only son died in a riding accident, he soon controlled the region itself. Later, one of his sons-in-law, Pomkha Namgyel Dörjé, served as commander-in-chief of Yilhung (Lhalung Chimé Dörjé and Dayang 2009, 184). In addition, he also arranged for some of his relatives and his trusted followers to establish marriage alliances with families of powerful headmen in Dergé as well as with Khangsar and Mazür chieftain families in Kandzé. ${ }^{34}$

\section{Jagö Topden and the 'Khampa Rule of Kham' Movement}

In the mid-1930s Jagö was quick to grasp the political situation in inland China, and fully understood the significance of the political developments. His appreciation of Chinese politics differentiated him to some degree from other more conservative traditional Khampa elites who were ill-informed of the dramatic changes taking place in China at the time. With political aspirations that went beyond simply restoring his family's authority and position in Dergé, he began to turn to larger affairs relevant to the entire Kham region. Extending his interest and participation in political activities outside of Dergé, he became one of the key political figures in Kham.

In 1935 Jagö became actively involved in the 'Khampa rule of Kham' movement launched by Gara Lama (also known as Nörla Hutuktu), an

33 See Lai Zuozhong (1996, 98); Baima Dengdeng and Xiake Zelang (20o8, 19-23); Lhalung Chimé Dörjé and Dayang (2009, 183); Lodrö Püntsok (1994, 151-152). Jagö Topden took two daughters of the Lhari chief as his wives. See Genzao Fashi and Mixian Fashi (1995, 30).

34 Jagö Topden also established a good relationship with important people from other regions by arranging marriage alliances between his trusted followers and other powerful chiefs and headmen. He had Juchung Tsedör of Juchung family become the son-in-law of the Khangsar chief's family in Kandzé; he had Jamga of Dimgo family become the son-in-law of the Atup Lakartsang family; and he had Rapga of the Zhingmo family marry into the family of Mazür chief in Kandzé. Thus, he had the support of chiefs and headmen in Kandzé. See Lhalung Chimé Dörjé and Dayang (2009, 184-185); Lai Zuozhong (1996, 98). 
influential lama from Riwoché monastery who harbored the ambition of driving both Lhasa troops and the warlord Liu Wenhui's troops out of Kham. In the 1930s, Khampa elites began to oppose interference from the Ganden Phodrang and the Nationalist authorities and also to promote the idea of self-rule for Khampas. Launched in 1932 by Kelzang Tsering, a representative of the modern 'educated elite', the movement strove for local autonomy with the aim of creating a unified Kham identity by asserting local power based on ethnicity. This represented a major strategy for Khampa elites to assert their influence in regional affairs. In 1935, when Gara Lama was dispatched by the Nationalist government to block the advance of the Red Army in Kham, he summoned powerful figures from various regions of Kham to Dartsedo (Kangding) to an assembly in which Jagö Topden participated (Jiang Anxi et al. 1983, 65; Feng Youzhi 1994, 145). Deeply attracted by the Gara Lama's idea of local autonomy, Jagö regarded 'the Khampa rule of Kham' movement not only as a means to restore the stability of Kham but also as a way to enable the Kham region to avoid interferences from both the Ganden Phodrang and the Nationalist government. According to the recollection of his brother, Jagö Tsenam, during the aforementioned assembly convened by Gara Lama, Jagö himself noted five guiding principles of 'implementing regional autonomy; striving for equality for all minzu; eliminating the ulak system; improving farming and herding techniques; and developing culture and education' and some tentative ideas and plans. ${ }^{35}$

At the beginning of 1936, Jagö, together with Pangda Topgyé, Gara Lama, and a key headmen under the Beri king in Kandzé known as Döndrup Namgyel (known as Deng Dejie in Chinese), secretly formed the group 'four harmonious friends' (tünpa pünzhi) to realize the political aspirations of the 'Khampa rule of Kham' movement that had been influenced by both Nationalists' and Communists' rhetoric. Jagö formed a close alliance with the Gara Lama and backed the latter's subordinates in killing Chen Rongguan, the Dergé Country magistrate; Zhang Ziyu, the Denkhok County magistrate; and others appointed by Liu Wenhui. However, the movement eventually had to be suspended due to the death of the Gara Lama. Nevertheless, Jagö Topden, Pangda Topgyé, and others continued to promote the 'Khampa rule of Kham' idea. However, the premise that Jagö would support and participate in the 'Khampa rule of Kham' movement was a guarantee that no external forces would interfere in the politics of Kham. This principle was reflected in how he dealt with another 'Khampa rule of Kham' movement launched by Panchen Lama's camp (zhükgar) and the Khangsar family in 
1939. Armed clashes broke out between the ninth Panchen Lama's camp and the Khangsar family on the one side and troops under the Chinese warlord Liu Wenhui stationed in Kandzé on the other side. The former, in the name of openly advocating 'the Khampa rule of Kham', sought military assistance from Jagö and the Dergé king, but Jagö refused to be involved in the conflict. Even though the ninth Panchen Lama's camp had appointed magistrates in Kandzé, Nyarong, and Drango counties, they were unable to interfere in Dergé affairs (Lhalung Chimé Dörjé and Dayang 2009, 191-192; Tsewang Düdül 1990, 492; Jagö Topden 1990, 492). This fully attests to the status and power that Jagö enjoyed at the time in Kham.

Jagö's stand during this period is noteworthy. Earlier he had actively supported Gara Lama's 'Khampa rule of Kham' movement and his military actions to oust the Chinese warlord Liu Wenhui's troops. For a number of reasons, Jagö began to shift his allegiance. First, Jagö changed his perception of the strength of Liu Wenhui's troops and understood that it was very difficult to dislodge them. Second, he was unwilling to jeopardize, as shown in the next section, his newly established ties with Liu Wenhui. Another reason for Jagö's distancing himself from the 'Khampa rule of Kham' movement was that he did not want Panchen Lama's camp to be the paramount force in northern Kham. In accordance with Püntsok Wangyel's recollection, like Kelzang Tsering, Jagö also viewed Khampas as a different ethnic group from Tibetans who lived to the west of Drichu River.$^{36} \mathrm{He}$ did not like the conduct and deeds of Lhasa aristocrats and of the Ganden Phodrang troops in Kham. In his view, when the Dergé chikhyap ruled Dergé at the beginning of the twentieth century, central Tibetans were regarded as the oppressors of Khampas (Goldstein et al. 2004, 54).

\section{Jagö Topden's Connection with the Red Army}

The Red Army's journey through the Kham region during their 'long march' provided Jagö with an opportunity to come into contact with and to learn about the Red Army's view points and policies. When the Red Army reached Tawu, Drango, and Kandzé in the spring of 1936, Jagö was dispatched by the Dergé king to Kandzé to block their advance (Lhalung Chimé Dörjé and Dayang 2009, 188; Lai Zuozhong 1996, 98-99; Zhonggong Ganzi zhouwei dangshi yanjiushi 2012, 185). ${ }^{37}$ Dergé forces were defeated by the Red Army,

36 The term mirik in Tibetan can be translated either as 'nationality' or 'ethnic group'.

37 Other officials include Wokma Chamdzö Sönam Tsering, Nyerchen Lodrö Jamyang, Drumo Tubten, Dekha Chimé. See Lhalung Chimé Dörjé and Dayang (2009, 188). 
and Jagö was injured and captured (Baima Dengdeng and Xiake Zelang 2008, 194; Lhalung Chimé Dörjé and Dayang 2009, 188). $3^{8}$ It appears that Jagö was well treated by the Red Army, and Li Xianian himself, the political commissar of the No. 30 Red Army met with Jagö (Li Xiannian zhuan bianxiezu deng 2011, 136; Lai Zuozhong 1996, 99; Zhonggong Ganzi zhouwei dangshi yanjiushi 2012, 186). The commander-in-chief of the Red Army, Zhu De, also met with Jagö, introducing to him the Communist Party's policies toward minzu and religion as well as its political opinions. While captive, Jagö sent a letter in Tibetan to the Dergé king, asking the king not to oppose the Red Army. He was later authorized by the Dergé king to sign a 'Non-Aggression Pact' with Wang Weizhou under the leadership of the Red Army representative Li Xiannian (Deng Junkang and Li Kunbi 2009, 1, 190; Lai Zuozhong 1996, 99; Zhonggong Ganzi zhouwei dangshi yanjiushi 2012, 186). In May 1936, under Zhu De's initiative, the Central Tibetan People's Government of the Chinese Soviet was established in the town of Kandzé, 39 and Jagö was elected as head of the military affairs department (Zhonggong Ganzi zhouwei zuzhibu 1991, 16-17; Den Junkang and Li Kunbi 2009, 19o; Zhonggong Ganzi zhouwei dangshi yanjiushi 2012, 187).$^{40}$ Without contemporary sources attesting to how the Khampa elites, including Jagö, understood the programme, it would be hard to determine whether the Kham elites genuinely believed in the Communists' vision or were simply being opportunistic. It seems clear, however, that the Khampa elites joined 'the Böpa Soviet' to oppose the warlord Liu Wenhui and the G.M.D. government rather than simply for the sake of an ideological conversion. Jagö and other Khampa leaders wanted Chinese Communist Party (C.C.P.) support to advance their own cause of achieving Kham self-rule. It is also possible that these Khampa elites were compelled to support the Red Army as the latter was the strongest military force at the time. ${ }^{41}$ Nonetheless, Jagö assisted Red Army soldiers and helped

38 Jagö Topden's troops mainly consisted of reincarnated lamas and monks from Gönchen monastery. They established their camp at Atup Ripuk in Rongpatsa; the forces under Wokma Chakdzö and Lodrö Jamyang set up their camp at Getok. The Red Army launched a surprise attack at night and defeated the Dergé forces. Wokma Chakdzö led his fleeing troops back to Dergé. See Lhalung Chimé Dörjé and Dayang $(2009,188)$.

39 The name of the soviet in Tibetan is krung hwa su'u we ed bod pa dbus sde pa mi dmangs srid gzhung, and in Chinese it is known as Zhonghua Suwei'an boba zhongyang renmin zhengfu.

40 For details about the Communists' visions for the pan-Tibetan organization and the Central Tibetan People's Government, refer to 'Guiding Principles of the Central Government of Tibetan People's Soviet' (Zhonggong ganzi zhouwei dangshi yanjiushi 2012, 112-113).

41 It seems that some of the Khampa youth, such as the educated Göngpo Tsering (Hai Zhengtao) and Trashi Wangchuk, who were appointed as directors in charge of military affairs, later became communists, and in particular Trashi Wangchuk, who joined the Red Army to travel north. 
the communists collect badly needed resources in Kham. It is reported that with Jagö's help the Red Army secured 400 yaks and 100 horses in the Kandzé area alone. He also provided guides and interpreters for the Red Army (Lai Zuozhong 1996, 99; Lhalung Chimé Dörjé and Dayang 2009, 190).42 Jagö's strong ties with the Communists and his ability to mediate between the Communists and Khampas enhanced his fame among both (Lhalung Chimé Dörjé and Dayang 2009, 189-19o; Lai Zuozhong 1996, 98-99; Baima Dengdeng and Xiake Zelang 2008, 194). ${ }^{43}$

\section{Jagö Topden's Relationship with Liu Wenhui}

After the Red Army had left the region, the Sichuan warlord Liu Wenhui began to reassert his power, and he had many reasons for targeting Jagö. He resented Jagö's involvement with Gara Lama, and Jagö's increasingly close contact with the Communists. In 1937, fearing that Liu Wenhui would retaliate against him, Jagö made plans to flee to Central Tibet. Liu Wenhui fully understood the importance of benefiting from the support of the Dergé king and other indigenous chieftains and headmen to ensure stability in Kham. Thereupon, he dispatched Fan Changyuan, Pelyül County magistrate, to meet with the Dergé king and his ministers. It was said that Fan brought a message from Liu that sought to win over the king and his ministers (Deng Junkang and Li Kunbi 2009, 190; Lhalung Chimé Dörjé and Dayang 2009, 190). Liu declared that he would not take action against those who had rallied behind Gara Lama in his attempt to drive Liu's forces out of Kham. It appears that the king was convinced by Liu's message, and he urged Jagö to apologize to Liu Wenhui in person (Lhalung Chimé Dörjé and Dayang 2009, 190; Lai Zuozhong 1996, 98-99). Although the situation appeared to be humiliating to Jagö, he was able to turn it round in his favour. The meeting between Jagö and Liu in Dartsedo provided an opportunity for Jagö to establish a personal relationship with Liu. ${ }^{44}$

\footnotetext{
42 It is interesting to note that the article written by Deng Junkang and Li Kunbi states that Jagö Topden gave 150 yaks, over 50 horses, and some grain to the Red Army. The amount mentioned in Lai Zuozhong's article is somewhat different, and it is possible that the amount provided in Deng Junkang and Li Kunbi's article refers to the amount provided by Jagö Topden himself. See Deng Junkang and Li Kunbi (2009, 190).

43 To block the advance of the Red Army, in 1936 the forces of the Qinghai warlord Ma Bufang also began to station in Dergé, Denkhok, Pelyül, and Sershül. This caused the Dergé king and his family to flee to Jomda west of the Drichu River.

44 They blamed Gara Lama for killing the magistrates of Dergé and Denkhok (Lhalung Chimé Dörjé and Dayang 2009, 190).
} 
Having realized the growing influence of Liu Wenhui in Kham compared to the declining authority of the Ganden Phodrang, Jagö saw the need to establish strong ties with Liu and also to become familiar with viewpoints of various Chinese authorities in Sichuan province. Thereupon, in 1938 Jagö attended the 'Institute of the Public Security and Administration of Xikang' (Xikang bao'an xingzheng jiangxihui) run by Liu Wenhui in Dartsedo. The institute was a modernist project aimed at bringing in local leaders for training in what were regarded as modern administrative skills. Although all local Khampa leaders were encouraged to attend the institute, they usually sent their servants or subordinate officials for training instead. Demonstrating his willingness to forego status and to actively learn modern knowledge, Jagö was the only senior leader who attended it (Ren Naiqiang $2009,188)$. His participation proved to be beneficial. Not only did he begin to learn Chinese, but his time at the institute also provided firsthand contact with emerging Chinese officials in Kham.

In 1939, Liu Wenhui became the chairman of the newly established Xikang province, which comprised the region of Chuankang (the Kham region in Sichuan province), the No. 18 administrative region of Sichuan province (the Xichang Yi region), and the No. 15 administrative region of Sichuan province (Ya'an). As a way of coping with Japanese attempts to invade Sichuan, Xikang province was established thanks to efforts to promote the construction of the area under G.M.D. rule far from the battlefront during the Anti-Japanese War of Resistance. As a result, Liu Wenhui began to further strengthen Kham's political rule, integrating more and more former indigenous chieftains and headmen in its administrative system. Impressed by Jagö's attitude and actions, Liu Wenhui appointed him deputy commander of the Xikang Special Public Security Brigade (xikang tezhong bao'an fu duizhang): this office gave Jagö the same rank as the Dergé king in the administration and made him one of the most powerful figures in Kham. Liu was later informed by Dergé County magistrate that Jagö could not occupy the same position as the king. The king was, therefore, given the title of regional deputy commander (Qu fuzhihui). On the surface, it seemed that power rested with the Dergé king, but Jagö Topden was the one who wielded the real power. This was demonstrated not only by outside groups negotiating with him but also, increasingly, by local people beginning to view him as such (Ren Naiqiang 2009, 188). Jagö's role and status in Liu's administration of Kham grew quickly. He occupied positions such as Councilor of Xikang Province (Ch. Xikang sheng canyiyuan) and Head Councilor of Dergé County (Dege xian canyizhang), etc. (Lhalung Chimé Dörjé and Dayang 2009, 190-191). Jagö accordingly made great efforts to implement all Xikang Provincial 
government's decrees and ordered the children of his family and relatives to take the lead in enrolling in Chinese schools in the region. All Chinese officials who had any contact with Jagö were believed to have praised him highly, and in Kham he enjoyed a great reputation (Ren Naiqiang 2009, 188).

Another means used by Jagö Topden to expand his power and authority was to join the Nationalist Party, ${ }^{45}$ and his action coincided with the period when the Nationalist Central Committee was making great efforts to extend the Nationalist Party's influence in Kham. After the Chinese warlord Liu Xiang, Chairman of Sichuan province, passed away in 1938, Chiang Kai-shek and Zhang Qun governed Sichuan successively. With efforts to control Sichuan and Kham, and to weaken the power holders in these regions intensifying after the creation of Xikang province in 1939, they took the measure to recruit new party members among the local elite and to establish Nationalist Party committees at provincial and county levels. Under the circumstances, Jagö also began to form a close association with other Khampas in the G.M.D., such as Pangda Topgyé, Kelzang Yeshé, Kelzang Chönjor (also known as Liu Jiaju, secretary-general of the ninth Panchen Lama's camp), and Döndrup Namgyel (Lai Zuozhong 1996, 99; Lhalung Chimé Dörjé and Dayang 2009, 191).

By 1940 Khampa politics became increasingly drawn into larger rivalries between the Communist and Nationalist Parties. Khampa elites were divided into three factional groups: those allied to the Nationalists, those in favor of the Communists, or those who sought to maintain the status quo and preserve local rulers. In particular, a new group of Khampas who allied with the Communists were those who had embraced new ideas and sought nothing less than total transformation of the social system. A notable example is Bapa Püntsok Wangyel, commonly known as Pünwang. He wrote: 'I began by developing a relationship with Chagö Tomden (Jagö Topden), one of the most famous aristocrats in Dergé. He was a member of one of the wealthiest and most powerful families and a top minister in the Dergé government. He had the ability to call up at a moment's notice an armed militia of hundreds [...]' (Goldstein et al. 2004, 53). Pünwang tried to wean Jagö away from Liu Wenhui, stating that Liu would not safeguard Dergé's independence. Liu's acceptance of Dergé's independence was merely temporary, as Liu had more pressing problems to deal with. Pünwang also began to propose a

45 Having been recommended for party membership by the Republican official Wan Tengjiao and the abbot of Nyintso (Nyatso; Nyi mtsho/Nya mtsho) Mawang Chöndzé (Machöwang; Mawur Chöndzé; Ma dbang chos mdzad/Ma chos dbang/Ma bur chos mdzad), Jagö joined the Nationalist Party. See Lai Zuozhong (1996, 99); Lhalung Chimé Dörjé and Dayang (2009, 191). 
new idea of establishing a pan-Tibetan movement that would encompass all Tibetan-speaking regions. Jagö was suspicious of the idea. Moreover, as Pünwang wrote, he had doubts about trying to dislodge the Chinese. He and his family would have a lot to lose by trying to expel the Nationalist troops and officials. He worried that if anything were done to remove the Chinese county government, more Chinese were sure to come into Kham' (Goldstein et al. 2004, 54-55). However, Jagö's falling out with Liu came from a more traditional form of political concern.

In 1942, King Tsewang Düdül passed away. The heir to the Dergé throne, Urgyenkyap (also known as Wuga), was only four years old. At the time, Jagö saw an opportunity to impose his choice of the candidate to the throne of Dergé; he proposed that Jampel Rinchen's son Kelzang Wangdül (1912-1984) marry his cousin's widow Jamyang Pelmo and succeed to the throne of Dergé. ${ }^{46}$ The proposal was unacceptable not only to Liu Wenhui but also to the faction supporting the Dergé family that descended from Dörjé Senggé. Kelzang Wangdül had been brought up as a member of Lhasa's aristocracy. ${ }^{47}$ Liu feared that the Lhasa government would be able to extend its influence to Dergé again through Kelzang Wangdül. Instead, the faction supporting Dörjé Senggés line suggested that the highly respected and revered Situ rinpoché of Pelpung monastery should act as temporary regent. Jagö's faction opposed their proposal for a number of reasons. First, it seemed that Dörjé Senggé's faction maintained closer ties with Pelpung monastery. Second, Jagö's faction feared that once a lama had been appointed it would be difficult to remove him from power (Lai Zuozhong 1996, 99; Lhalung Chimé Dörjé and Dayang 2009, 191-194). The issue was finally settled by having Tsewang Düdül's widow, Jamyang Pelmo, act as regent until the heir reached majority. Liu Wenhui knew clearly that Jagö Topden was craving a power base for himself and was increasingly becoming one of the most influential figures among the Khampa leaders. In addition, Liu was not sure whether Jagö was loyal to him. In 1944, Jagö had one of his rivals, the Atup chief Wangga in Kandzé assassinated. Wangga was 'the indigenous battalion commander' appointed by Liu Wenhui and was also a loyal follower of Liu. It was a well-known fact that Jagö was behind the assassination. Thus, Liu ordered

46 Jagö is also believed to have proposed to take charge of Tsewang Düdül's illegitimate son, whose name is unknown. He was brought up by Jagö to succeed to the throne of Dergé, but this was also opposed by the other party. See Chengdu junqu silingbu $(1957,8)$.

47 In 1943, when appointed as the attendant with the fourth rank for Yutok dzasak Trashi Döndrup, the Commissioner of Domé, Kelzang Wangdül accompanied the latter to take up position in Chamdo. In 1946 he became the ninth regiment commander, who was dispatched to garrison Drayap first and was later stationed in Markham. 
Gong Gengyun, the commander-in-chief of the Security Forces of Region Six in Dergé, to execute Jagö for the crime. Before Gong could carry out the order, Dergé magistrate Fan Changyuan, who was also an intelligence officer of the Military Commission of the G.M.D. Government, informed Jagö of Liu's order and allowed him to escape arrest and execution.

\section{Contesting the Authority of the Regent}

When Jamyang Pelmo began to serve as regent in Dergé, she seemed to be well aware of Jagö's growing power and authority, and considered the latter as a major threat to her son's future rule. To counter Jagö, Jamyang Pelmo relied on his rivals, including two chief ministers Wokma Chakdzö Sönam Tsering and Juchung Tsedör. With these officials wielding the actual power at Dergé royal court, Jagö was to a certain degree pushed aside by them (Lhalung Chimé Dörjé and Dayang 2009, 197). ${ }^{48}$ In 1946, Wokma Chakdzö instigated his subordinates to hold a feast for Jagö Topden and planned to poison the latter on this occasion. Because Jagö became aware of the plan, the conspiracy failed. This intensified Jagö's conflict with the Dergé king's faction even further. Having refused to return to the Dergé king's central government in Gönchen, Jagö returned to his family seat in Yilhung, thereby openly breaking with Jamyang Pelmo (Chengdu junqu silingbu 1957, 6-7; Den Junkang et al. 2009, 190-191; Lhalung Chimé Dörjé and Dayang 2009, 195, 201-214; Lodrö Püntsok 1994, 197-200).

In the same year, a dispute over pastureland led to the assassination of Drebö Lhagyel, a headman in Pelyül, by two families in Menshör - the Sokmo and Juchung families. The two headmen's families were supported by the Dergé king's family, while the Drebö family had been on friendly terms with the Jagö family for generations. Thus, the rift between the Dergé king's faction and the Jagö faction deepened further. ${ }^{49}$ At the time, having realized the importance of establishing his own power base, Jagö began to adopt a more populist approach. He redefined himself as a social reformer

48 In reality, when Jagö Topden became chief minister (nyerchen) in charge of daily affairs in Dergé in 1929 and later when he gained the trust of King Tsewang Düdül, it caused his rivals to resent him. The rivals formed an alliance to compete against Jagö for power and authority.

49 The Drebö family was Ngawang Jampel Rinchen's loyal supporters who, together with Jagö's family, followed the latter to Central Tibet. Jagö harbored great animosity toward the headmen who had assassinated Drebö Lhagyel and were also hostile toward and harbored grudges against Jamyang Pelmo. See Lai Zuozhong (1996, 100); Den Junkang et al. (2009, 191); Baima Dengdeng and Xiake Zelang (2008, 197-199). 
and defender of ordinary people against the royal family. Thus, in 1947 he openly advocated deposing the Dergé royal family, eliminating the 'tusi system', and abolishing the corvée labour system..$^{50} \mathrm{He}$ also called himself 'Yilhung tusi' and 'gyalo gyelpo' (literally meaning 'A-hundred-year-old king') (Chengdu junqu silingbu 1957, 9). He further proposed to establish 'Miser Gyelkhap' (The People's Nation), where 'the Khampa rule of Kham' would be implemented (Lai Zuozhong 1996, 100; Baima Dengdeng and Xiake Zelang 2008, 201). The use of the term miser (originally meaning 'serf' or 'subject'; in this context, having the connotation of common people or citizen $)^{51}$ is interesting and clearly signifies a radical transformation. In the same year, Jagö urged local people not to provide corvée labour to the Dergé king's family to repair the government office. As a consequence, only one third of trelpa (tax-payer) families provided corvée labour. In one or two places armed resistance even emerged against providing corvée labour (Zhongkeyuan minzu yanjiusuo Sichuan diaochazu 1963, 32). After the three major families in Menshör went into exile following their dispute with the Drebö family, Jagö also distributed their land, houses, and grain to their tenants. This action was warmly welcomed by poor households and began to attract other farmers to his cause (Lai Zuozhong 1996, 100; Baima Dengdeng and Xiake Zelang 2008, 201).

Soon after the Dergé regent dispatched her subordinate officials to levy grain taxes in Hörpo of Pelyül dzong, Jagö Topden ordered various villages to refuse to hand them over. The regent decided to dispatch troops to levy the grain taxes, and Jagö assembled local forces to resist them. With the support of the common people, he had the dzongpön (magistrate) dispatched by the Dergé king driven out of Hörpo..$^{2}$ Jagö's strategy proved to be popular, and people of many areas under Dergé's influence began to follow him. His power and authority also gradually increased. Consequently, in one of his articles published in 1947, Ren Naiqiang, the famous Chinese ethnologist and Tibetan Studies expert of the Republican period, portrayed Jagö as the

$5^{0}$ See Jagö Topden's letters to He Long and Deng Xiaoping dated 5 January 1951, in the Sichuan Archives.

$5^{1}$ For the meaning of the term miser, refer to the relevant entries in Goldstein (2001, 805).

$5^{2}$ The villagers elected the commoner Pema Chömpel as dzongpön with support from Jagö. While Jagö dispatched Nyaktrük Rinchen to serve as zhinyer (manager in charge of 200 households) in Hörpo of Pelyül, he also sent Dzakhok rinpoché Pema Ngenam to be dzongpön of Rakha in Pelyül. In addition, he also appointed his close follower Nyaktrük Lhagyel, a leading headman, as dzongpön of Dzinkhok, and appointed the commoner Wola Wangdzin as zhinyer of Barong in Pelyül. See Lai Zuozhong (1996, 100-101); Baima Dengdeng and Xiake Zelang (2008, 201). 
most powerful indigenous leaders in Kham (Ren Naiqiang 2009, 188). In 1947, the Chinese masters Genzao and Xianmi spent over a year at Jagö's home in Yilhung, when they went to study esoteric Buddhism in Kham. Jagö's great reputation and strong links with other Khampa leaders and reincarnated lamas was reflected in their account. During their stay at his home, Genzao and Xianmi reported that many guests came to visit him. In particular, many reincarnated lamas came to recite prayers and scriptures (Genzao Fashi and Xianmi Fashi 1995, 30). In addition, a Chinese monk named Tongxiao Fashi, who had studied for ten years in Lhasa, learned that Jagö Topden was a famous person in Kham and came to pay the latter a visit at home on his way to Kandzé via Yilhung (Genzao Fashi and Xianmi Fashi 1995, 50).53

By the 1950s, Jagö's faction consisted of nearly 100 major and minor headmen, with over 17,00o households under their jurisdiction. Their power and authority predominated in Pelyül, Denhok, Sershül, and Dergé counties, thereby becoming a major political network in northern Kham. In contrast, the Dergé king's family had only $5^{\circ}$ or so major and minor headmen under its control, with approximately 5000 households under their jurisdiction. The Dergé king's family had power and authority mainly over most parts of Tangpuk (present-day Jomda County), such areas as Gönchen, Menshör (also known as Meshö), Pelpung and Pewar in Dergé County, as well as regions under the jurisdiction of the Atup family in Denkhok. (Qin Heping 2014, 65-79; Chengdu junqu silingbu 1957, 1, 18).

As mentioned above, the campaign launched by Jagö in 1947 exemplified an apparent switch in his political strategy in terms of mobilizing and appealing directly to the people. He campaigned under the slogan 'Don't provide corvée labour for the tusi and don't hand in grain tax to the tusi' (bugei tusi fu chaiyi, buxiang tusi jiao fushui). ${ }^{54}$ Realizing that Jagö was gaining popularity and was becoming a growing threat to the Dergé court, the Dergé regent, Jamyang Pelmo, planned to assemble her subordinates and to unite with the troops of her brother (i.e. the Nangchen king) so as to counter Jagö's rise by force. The growing influence of Jagö in Kham also presented a challenge to the warlord Liu Wenhui, who secretly ordered the regimental commander Fu Dequan to gather his troops in Kandzé and to prepare to make a move against Jagö as well. In 1949 the Communist

53 According to Masters Genzao and Mixian, they were introduced to Jagö Topden by Döndrup Namgyel (Deng Dejie) whom they met in Dartsedo. In 1954, at Jagö Topden's invitation, they again travelled to study under Gyelsé rinpoché at Ngazang monastery in Tromtar, Pelyül. See Genzao Fashi and Mixian Fashi (1995, 10, 85, 94-100).

54 These slogans were probably originally in Tibetan, but the Chinese source provided them in Chinese. 
Party defeated the Nationalist Party and ultimately became victorious. In November of the same year, Jagö Topden, Getak rinpoché, and others sent representatives to Beijing to pay respect to the Chinese Central Government and Chairman Mao Zedong, by presenting them with banners. They requested that Tibetan regions be liberated. ${ }^{55}$ The Dergé court and Liu Wenhui's campaign against Jagö collapsed as the No. 18 army of the P.L.A. took over Dergé in June 1950 (Lai Zuozhong 1996, 101; Lhalung Chimé Dörjé and Dayang 2009, 215).

Both Jagö Topden and Jamyang Pelmo dispatched their representatives to welcome the P.L.A., expressing their willingness to support the Communist Party and the Chinese central government. At the time, Jagö served as deputy director of Kangding Military Control Commission (Kangding junguanhui). He contacted Getak rinpoché, Pangda Topgyé, and others, and they wrote a letter to General Liu Bocheng (1892-1986), chairman of the Southwest Military and Political Commission (xinanjunzheng weiyuanhui zhuxi). In the letter, they expressed their willingness to support the Communist Party and requested that national autonomy and self-management be implemented in Tibetan areas in Xikang. ${ }^{6}$

Uninterested in allying themselves with particular factions in Kham, the Communists, unlike previous Chinese regimes, were not bothered about playing one faction against another. They were motivated by broader issues of bringing the entire Kham region within the realm of the central administration. They could achieve this only by co-operating with different Khampa factions and interest groups. Thus, through mediations with multi-parties, Jagö Topden and Jamyang Pelmo eventually ended their estrangement and resolved their conflict. ${ }^{57}$ Meanwhile, the Communists realized that each Kham faction had to be appeased without seeming to favor one particular group. While Jagö Topden was appointed member of the Southwestern Military and Political Commission as well as vice-chairman of the People's Government of Xikang Provincial Tibetan Autonomous

55 The representatives dispatched by them stated 'Tibetan compatriots' longing for being liberated quickly', and their willingness to accept the leadership of the Chinese Central Government. Zhu De met with these representatives on 19 February 1950. See Wu Dianyao $(2006,1367)$.

56 See the original letter written by Jagö Topden and others to Liu Bocheng of the Southwest Military and Political Commission, in the Sichuan Archives.

57 Jagö Topden wrote to He Long and Deng Xiaoping, thanking them for sending a message to him. In his letter, he mentions that in their message they hoped he would make an effort to get along with Jamyang Pelmo and to achieve unity between them. He also expresses his willingness to take the lead in resolving the conflicts between the Dergé king's family and the common people. See Jagö Topden's original letter to He Long and Deng Xiaoping on 5 January 1951, in the Sichuan Archives. 
Region (Xikang sheng zangzu zizhiqu renmin zhengfu), Jamyang Pelmo was appointed deputy director of the Chamdo Regional Liberation Committee (Changdu diqujiefang weiyuanhui) (Deng Junkang and Li Kunbi 2009, 191)..$^{8}$

In the early period of Communist rule, unlike in Chinese provinces that were populated by Han Chinese, in ethnic minority areas the Communists did not seek to eliminate traditional ruling families, as they were aware that the Communists had very little support or organizational bases. Communist rule in minority areas would be achieved through appeasement and incorporating the ruling elite. The Communists' dealings with Jagö Topden provide a good example of this strategy. In the early 1950s, Jagö was appointed to be a member of the National People's Congress (quanguo renda daibiao), vice-chairman of Sichuan Provincial Political Consultative Conference (Sichuan sheng zhengxiefuzhuxi), deputy governor of Kandzé Tibetan Autonomous Prefecture (Ganzi zangzu zizhizhou fuzhouzhang), and vice-chairman of Kandzé Tibetan Autonomous Prefectural Political Consultative Conference (Ganzi zangzu zizhizhou zhengxie fuzhuxi). Jagö played a crucial role in helping the government of the People's Republic of China establish political power in Kham, and this is why he surpassed other monastic and lay elites in Kham (Qin Heping 2014, 65-79). In particular, given his cooperation with the C.C.P., later Chinese sources credit Jagö with having made great contributions to the regional autonomy of Tibetan areas of Xikang province and having provided assistance to P.L.A.'s march toward Central Tibet (Deng Junkang and Li Kunbi 2009, 191-192).59

$5^{8}$ Jamyang Pelmo was successively appointed member of the People's Government of Xikang Provincial Tibetan Autonomous Region and vice-chairman of Xikang Provincial Tibetan Autonomous Regional Political Conference (Xikang sheng zangzu zizhiqu zhengxie). She also served as deputy-director of Kangding Regional National Consultative Conference (Kangding diqu minzu xieshanghui), member of Southwest Democratic Women's Federation (xinan minzhu funü lianhehui), deputy-director of Xikang Provincial Women's Federation (Xikang shengfulian), executive committee member of All China Democratic Women's Federation(Zhonghua quanguo funü lianhehui), etc. See Deng Junkang and Li Kunbi (2009, 185-187).

59 Tibetan areas of Xikang province were equivalent to present-day Kandzé Prefecture. As Qin Heping has pointed out, Jagö's attitude toward 'democratic reform' is ambivalent. He basically accepted the reform and did not cause too much 'trouble'. However, the reform affected his personal vital interests and those of his respective class. As such, his words and actions were inconsistent with his understanding. It was said that Jagö began to have misapprehensions about the reform and became undecided about it. He even adopted some 'extreme' measures concerning the reform. The reason for his ambivalence about the reform was not only due to his personal concerns but also to the ambiguity of the reform's principles and policies adopted at the time. These principles and policies influenced his words and actions. See Qin Heping (2014, 65-79). 
The victory of the Communists meant a total shift in the nature of politics in Kham. Neither Jagö nor any other Kham leaders were able to deal effectively with the Communists. In part, this was because of the vast superiority of the Communist forces in terms of both their number and fighting capacity. More importantly, the Communists were united by a clear ideological objective. The arrival of the Communists marked the end of the traditional political system in Kham and of Jagö's personal ambition. Jagö died of an illness in 1960, thereby ending his legendary life.

\section{Conclusion}

The figure of the ambitious and charismatic Jagö Topden and his rise in both the politics of the kingdom of Dergé and that of the larger Kham region, is an exceptional example of the new elite that emerged in Kham at the end of the nineteenth century and the beginning of the twentieth century. As a representative of the new educated elite in Kham who challenged the traditional authority, Jagö Topden however differs from other representative figures of this new elite group. Many of the Khampa elite, such as Kelzang Tsering, were politically active in inland China itself; similarly, the religious elite in exile in inland China, represented by Gara Lama, were active not only in Kham but also in inland China. Although Jagö Topden had to contend with various political forces outside the Kham region, his political activities were mainly concentrated in Kham.

The ascendancy of Jagö Topden, who was a subordinate headman under the Dergé king, is also the epitome of the declining power of the traditional hegemonic rulers and the rise of their subordinate headmen during the Republican period. The rise of these headmen was partly the consequence of the weakening and even destruction of the traditional hegemonic ruler's power in Kham in the aftermath of the policy of substituting chieftains with state-appointed civilian officials that was implemented by Zhao Erfeng in the 190os. It was also closely related to the traditional political structure of hegemonic rulers, such as the Dergé king, which was decentralized and based on the hereditary hierarchy. In particular, the decentralized political structure caused hegemonic rulers to divide the land among local hereditary headmen, and this enabled the latter to form alternative foci of power that could counter the authority of hegemonic rulers. Consequently, these headmen were able to set themselves up as territorial rulers in the regions under their jurisdiction, to become excessively powerful, and to maintain a high degree of local autonomy. We can see that a similar structure allowed 
for the emergence and rise of headmen in Gyelrong regions during the Republican period.

This case study reveals how the negotiated space of the Kham frontier was transformed into the fixed 'place' of the newly established modern Chinese nation. It also demonstrates the complex, multivariant interactions between the local Chinese governments and the local power holders and indigenous chieftains (tusi) in the frontier zone. During the Republican period, Kham formed special internal political and cultural frontiers of the Republic of China together with other regions in the half-moon-shaped zone extending from Gansu and Qinghai regions in the northwest to the Yunnan-Guizhou plateau in the southwest. At the time, in the newly imagined geo-space of the Republic of China, frontier people were inscribed as co-nationals and the contested Kham region emerged as an inalienable part of the Chinese national space (Tsomu 2012).

As exemplified by the case of Dergé discussed in this chapter, successive warlords who governed the Kham region, such as Liu Wenhui, managed to extend the administrative control of the state over Kham polities and incorporate into the bureaucratic system the former hegemonic rulers and headmen who had only temporarily restored their power and authority at the beginning of the Republican period by appointing them at different levels of the new administration (Kangding minzu shizhuan bianxiezu 1994, 49). Meanwhile, they similarly integrated newly risen self-made leaders in southern Kham in local government institutions (Chen Peibin 2014, 174). In addition, the representative reincarnated lamas and eminent monks in Kham had been appointed to various government and party positions, including commissioner and adviser of Xikang province, councilor and alternate councilor of the First Provisional Council of Xikang province, among other important positions (Wang Chuan 2006, 81-82). ${ }^{60}$

The Republican period is characterized by a regionalization process involving the emergence of forms of regional consciousness and regional politics (Duan Jinsheng 2014, 31-40). Consequently, as this chapter shows, the Nationalist central government's influence was rather limited due to fierce resistance by local warlords in Kham, who remained dominant

6o They also held positions such as delegate of the National Assembly of Xikang province, member of the Supervisory Committee of the Nationalist Central Committee, and member of the Supervisory Committee of Sichuan Provincial Nationalist Party Headquarters, etc. Furthermore, while some of them were also elected president of the Buddhist Society at county level, others were selected to serve as master to propagate Buddhism (xuanjiao shi/xuanhua shi) and master to safeguard Buddhism ( fujiao shi), who were responsible for assisting in supervising local government affairs and playing the role of helping local military and government organizations to pacify local society. See Wang Chuan (2009, 80-81). 
in the administration of the region. Indeed, local secular and religious leaders were not passive participants. As the case of Jagö shows, to adapt to the new political order and to consolidate their own position in local society, local leaders took the initiative to maintain good relations with the Chinese authorities in order to play a more important role in the Chinese administration of the region. Thereupon, during the Republican period, three major forces co-existed: the Nationalist bureaucratic warlords, the former tusi (indigenous chieftains), and the headmen and the new self-made leaders as well as major monasteries. ${ }^{61}$ No matter which force was dominant in handling government affairs, as the case of Dergé shows, local leaders and monasteries still controlled local society; government officials had to rely on them to levy corvée labour and grain taxes. The relationship between the Chinese governments and the tusi in the Kham region was entirely similar to that of other frontier regions in the northwest and southwest where tusi ruled, as described by Lin Chunsheng, the Chinese ethnologist and anthropologist of the Republican period (Lin Chunsheng 1944, 8-9).

The new twentieth-century Kham elite represented by Jagö Topden was the product of this particular historical period in Kham - an era of enormous political and social change. Unlike the majority of traditional forces in Kham, who had a parochial outlook and only cared about what happened in territories under their jurisdiction, Jagö Topden and other new Khampa elites were more open-minded and farsighted. Therefore, they were able to emerge as the new leading figures in Kham politics at that time. After Jagö's return to Dergé in the early 1920s, over the following 30 years during which various powers competed for control of the Kham region, he continuously fought on several fronts against the Dergé king's family, the Ganden Phodrang in Lhasa, the Chinese warlord Liu Wenhui of Xikang, and the Muslim warlord Ma Bufang of Qinghai Province. By competing and negotiating with these different political figures, he acquired an understanding of their respective political views, and also constantly extended his power and authority by collaborating with them whenever possible. Thus, in the 1930 and 1940 s he became one of the most influential leaders in the history of Kham and was able to contest the authority of the king of Dergé. Jagö Topden also legitimized his authority through both the construction of a regional identity of a politically united Kham and the appropriation of new ideas and reforms. In this guise, Jagö appeared to be both modern and progressive. He was certainly aware of the undergoing ideological and social changes in inland

61 As for which force was dominant in the administration of the local counties in Kham, there were distinctive regional differences. For details, see Chen Peibin (2014, 173-174). 
China. He effectively adopted the populists' cause of social reform, was able to wrest power from the king, and positioned himself as the paramount authority in Dergé. In the dispute for control of Kham in general, and over Dergé in particular, the successive Chinese regimes, from the Qing to the establishment of the People's Republic of China and the Ganden Phodrang under the Thirteenth Dalai Lama, created a period of instability. Amidst this unrest, Jagö Topden, regarded as the 'political strongman' who had kept up with the times and was adept at acting as mediator between different power holders at local, regional, and state levels, proved to be a skillful player on the political chessboard as demonstrated by his connivance with external powers as well as by his appeal for popular support. As Dáša Mortensen's study of Wangchuk Tempa, another prominent local leader in southern Kham (in this volume), shows, Jagö Topden's savvy negotiation and 'collaboration' with various powers also demonstrates the degree of control exerted by local leaders in Kham during this turbulent era. The people of Dergé were tired of the instability and saw Jagö as a leader who could ensure peace in the territory. Thus, they allowed Jagö to emerge as the new independent ruler of Dergé. Had it not been for the victory of the Communists and the establishment of the People's Republic of China, Jagö Topden might well have become the new ruler of Dergé.

\section{Glossary of Tibetan Terms}

amban

Aja

Atup

Atup Lakartsang

Atup Ripuk

Adzom

Baba

Bapa Püntsok Wangyel

Barong

Bathang

Beri

Böpa

chakdzö

Chakdzö Namsé Tsega

Chakdzö Wokma Sönam Tsering am ban

A ja

A thub

A thub l'a dkar tshang

A thub ri phug

A 'dzom

Ba ba

'Ba' pa Phun tshogs dbang rgyal

Ba rong

'Ba' thang

Be ri

Bod pa

phyag mdzod

Phyag mdzod Rnam sras tshe dga'

Phyag mdzod 'Ok ma Bsod nams tshe ring 
Chakzamkha
Chamdo
chapsi kyi chawarkhedzang denpa

Chaktreng

Chimé Tapei Dörjé

chipöngo

chösi zungdrel

Chöying Zangmo

Chungrampa

Dabpa

Damtsik Dörjé

dapön

Dartsedo

Dechen Wangmo

dechok

Dekha Chimé

Denkhok

depa

Dergé

Dergé chikhyap

Dergé Gönchen

Dilgo

Dimgo

Domé chikhyap

Döndrup Namgyel

Dörjé Namgyel

Dörjé Senggé

Drango

Drebö

Drebö Lhagyel

Drichu

Drongpa

Drumo Tubten

drungyik

dünkör

dünkörkhak

Dzakhok rinpoché Pema Ngenam

Dzatö
Lcags zam kha

Chab mdo

chab srid kyi bya bar mkhas mdzangs

ldan pa

Phyag phreng

'Chi med rtag pa'i rdo rje

phyi dpon 'go

chos srid zung 'brel

Chos dbyings bzang mo

Khyung ram pa

'Dab pa

Dam tshig rdo rje

Mda' dpon

Dar rtse mdo

Bde chen dbang mo

Sde phyogs

'Das kha 'Chi med

'Dan khog

sde pa

Sde dge

Sde dge spyi khyab

Sde dge dgon chen

Dil mgo

Dis mgo

Mdo smad spyi khyab

Don grub rnam rgyal

Rdo rje rnam rgyal

Rdo rje seng ge

Brag 'go

Bre 'bod

Bre 'bod Lha rgyal

'Bri chu

'Brong pa

Gru mo Thub bstan

drung yig

mdun skor

mdun skor khag

Rdza khog rin po che Pad ma nges

rnam

Rdza stod 


\begin{tabular}{ll} 
Dzinkhok & 'Dzin khog \\
Dzokchen & Rdzogs chen \\
dzong & rdzong \\
dzong go & rdzong 'go \\
dzongkhak & rdzong khag \\
dzongpön & rdzong dpon \\
Gamongna & Rga mong sna \\
Ganden Phodrang & Dga' ldan pho brang \\
Gara Lama & Mgar ra bla ma \\
Garjé & Sgar rje \\
Gelong & Dge slong \\
Getak rinpoché & Dge rtag rin po che \\
Getok & Gad thog \\
Gojo Samdrup & Go 'jo Bsam grub \\
Golok & 'Go log \\
Gönchen & Dgon chen \\
Gönpo Namgyel & Mgon po rnam rgyal \\
Göngpo Tsering & Mgon po tshe ring \\
gopa & 'go pa \\
Göza & Mgos gza' \\
Göza Wanggyel & Mgos gza' dbang rgyal \\
gyalo gyelpo & bgya lo rgyal po \\
Gyantsé & Rgyal rtse \\
Gyangkham Dechen & Gyang khang bde chen \\
Gyari Chimé Drölma & Rgya ri 'chi med sgrol ma \\
gyelpo & rgyal po \\
Gyelsé rinpoché & Rgyal sras rin po che \\
Hakhok & Hya khog \\
Hörcho Peldo & Hor cho pad rdor \\
hördra & hor 'dra \\
Hörpo & Hor po \\
Jagö Pema Ledrup & Bya rgod Pad ma las grub \\
Jagö Tashi Namgyel & Bya rgod Bkra shis rnam rgyal \\
Jagö Topden & Bya rgod Stobs ldan \\
Jagö Tsenam & Bya rgod Tshe rnam \\
Jamga & 'Jam dga' \\
Jampa Künga Sanggyé Tenpai & Byams pa kun dga' sangs rgyas bstan \\
Gyeltsen & pa'i rgyal mtshan \\
Jampa Tendar & Byams pa bstan dar \\
Jamyang Pelmo & 'Jam dyangs dpal mo \\
& \\
& \\
\hline
\end{tabular}


Jamyang Zhepa

Janggyap

Jomda

jöntang chenpo

Juchung

Juchung Tsedör

Kagyü

Kalön Lama

Kamtok dröching

Kamtok dröchö

Kangpé rangdé rangpön

Kangpé rangsi rangkyong

Kandzé

Kelzang Chönjor

Kelzang Püntsok

Kelzang Tsering

Kelzang Wangdül

Kelzang Yeshé

khadrak wangshechen

Kham

Khampa

Khangsar

Khangsar Kyamgön

Khangsar Yangchen Khandro

Khangsar Yangchen Drölma

Kharnang

Khemé

khenpo

khölpa

Labrang Trashikhyil

Lhari

Lhasa

Lhundrupteng

Lingtsang

Lithang

Lodrö Jamyang

Lodrö Püntsok

Machöwang

Markham

Mawang Chöndzé
'Jam dbyangs bzhad pa

Byang rgyab

'Jo mda'

'jon thang chen po

'Ju chung

'Ju chung Tshe rdor

bka' rgyud

Bka' blon bla ma

Skam thog gros chings

Skam thog gros chod

Khams pas rang sde rang dpon

Khams pas rang srid rang skyongs

Dkar mdzes

Bskal bzang chos 'byor

Bskal bzang phun tshogs

Bskal bzang tshe ring

Bskal bzang dbang 'dul

Bskal bzang ye shes

kha drag dbang shed can

Khams

khams pa

Khang gsar

Khang gsar skyabs mgon

Khang gsar Dbyangs can mkha' 'gro

Khang gsar Dbyangs can sgrol ma

Mkhar nang

Khe smad

mkhan po

khol pa

Bla brang bkra shis 'khyil

Lha ri

Lha sa

Lhun grub steng

Gling tshang

Li thang

Blo gros 'jam dbyangs

Blo gros phun tshogs

Ma chos dbang

Smar khams

Ma dbang chos mdzad 


\begin{tabular}{ll} 
Mawur Chöndzé & Ma bur chos mdzad \\
Mazür & Ma zur \\
Meshö & Sme shod/Sman shor \\
Menshör & Sman shor \\
mi chen po & mi chen po \\
mirik & mi rigs \\
miser & mi ser \\
Miser Gyelkhap & Mi ser rgyal khab \\
Nakchu & Nag chu \\
namrik denpa & rnam rig ldan pa \\
Namsé Tsega & Rnam sras tshe dga' \\
Nangchen & Nang chen \\
Nangsotsang & Nang so tshang \\
Ngawang Jampel Rinchen & Ngag dbang 'jam dpal rin chen \\
Ngör & Ngor \\
Ngör khenchen Jampa Künga & Ngor mkhan chen Byams pa kun dga' \\
Tendzin & bstan 'dzin \\
Nörla Hutuktu & Nor bla/lha Hu thug thu/Ho thog thu \\
Nyachukha & Nyag chu kha \\
Nyarong & Nyag rong \\
Nyarong chikhyap & Nyag rong spyi khyab \\
Nyarong Gönpo Namgyel & Nyag rong Mgon po rnam rgyal \\
Nyakshik Setsa & Nyag shig se tsha \\
Nyaktrük Lhagyel & Nyag phrug Lha rgyal \\
Nyaktrük Rinchen & Nyag phrug Rin chen \\
nyerchak lhengyekang & gnyer phyag lhan rgyas khang \\
nyerchen & gnyer chen \\
Nyerchen Gyangkhang rinpoché & Gnyer chen Gyang khang rin po che \\
Nyerchen Lodrö Jamyang & Gnyer chen Blo gros 'jam dbyangs \\
Nyingma & Rnying ma \\
Nyintso & Nyi mtsho \\
Nyatso & Nya mtsho \\
Pangda Topgyé & Spang mda' Stobs rgyas/Spom mda' \\
Pangdatsang & Stobs rgyas \\
Pelpung & Spang mda' tshang \\
Pelyül & Dpal spungs \\
Pelyül dzong & Dpal yul \\
Pema Chömpel & Dpal yul rdzong \\
Pema Wangchok & Pad ma chos 'phel \\
& Pad ma dbang mchog \\
& \\
\hline &
\end{tabular}


Penpo

Pomda Topgyé

Pomdatsang

Pomkha Namgyel Dörjé

pönchenzhi

pöngozhi

pönpo

Püntsok Wangyel

Pünwang

Ragashak

Rakha

Rapga

Raru Jamyang Lobdrö

Riwoché

Rongpatsa

Sakya

Sera

Sershül

Situ rinpoché

Sokmo

Sokmotsang

Sönam Chömtso

Sönam Tsomo

Tangpuk

Tawu

theji

Trashi Wangchuk

trelpa

Tromtar

Tsari

Tsari Nyergé

Tsang

tsé lopdra

Tseten Drölkar

Tsewang Dörjé Rikdzin

Tsewang Drölma

Tsewang Düdül

Tsewang Lhamo

Tsolho

tünpa pünzhi
'Phan po

Spom mda' Stobs rgyas

Spom mda' tshang

Spom kha Rnam rgyal rdo rje

dpon chen bzhi

dpon 'go bzhi

dpon po

Phun tshogs dbang rgyal

Phun dbang

Ra ga shag

Ra kha

Rab dga'

Ra ru'Jam dbyangs blo gros

Ri bo che

Rong pa tsha

Sa skya

Se ra

Ser shul

Si tu rin po che

Sog mo

Sog mo tshang

Bsod nams chos mtsho

Bsod nams mtsho mo

Thang phug

Rta'u

tha'i ji

Bkra shis dbang phyug

khral pa

Khrom thar

Rtsa ri

Rtsa ri Gnyer dge

Gtsang

rtse slob grwa

Tshe brtan sgrol dkar

Tshe dbang rdo rje rig 'dzin

Tshe dbang sgrol ma

Tshe dbang bdud 'dul

Tshe dbang lha mo

Mtsho lho

mthun pa spun bzhi 


$\begin{array}{ll}\text { ügön } & \text { dbu dgon } \\ \text { üla } & \text { dbu bla } \\ \text { ulak } & \text { 'u lag } \\ \text { Urgyenkyap } & \text { O rgyan skyabs } \\ \text { Wangga } & \text { Dbang dga' } \\ \text { Wangpotö } & \text { Dbon po stod } \\ \text { Wokma Chakdzö Sönam Tsering } & \text { 'Og ma phyag mdzod Bsod nams tshe } \\ & \text { ring } \\ \text { Wola Wangdzin } & \text { 'O la dbang 'dzin } \\ \text { Wönpoteng } & \text { Dbon po steng } \\ \text { Wuga } & \text { O dga' } \\ \text { Yardrok Yumtso } & \text { Yar'brog g.yu mtsho } \\ \text { Yilhung } & \text { Yid lhung } \\ \text { zhika } & \text { gzhis ka } \\ \text { Zhingmo } & \text { Zhing mo } \\ \text { zhinyer } & \text { gzhis gnyer } \\ \text { zhükgar } & \text { bzhugs sgar } \\ \text { zimpön } & \text { gzim dpon }\end{array}$

\section{Glossary of Chinese Terms}

Anzhang (si)

bugei tusifu chaiyi, buxiang tusijiao fushui

Chailiang zongban

Changdu diqu jiefang weiyuanhui

Chen Rongguang

Chiang Kai-shek

Chuankang

Dege xian canyizhang

Deng Dejie

Deng Junkang

Deng Xiaoping

dusi

Fan Changyuan

Fu Dequan

fujiao shi

gaitu guiliu

Gansu

\section{安章 (寺)}

不給土司服差役, 不向土司交賦稅

差糧總辦

昌都地區解放委員會

陳榮光

蔣介石

川康

德格縣參議長

鄧德傑

鄧俊康

鄧小平

都司

範昌元

付德銓

輔教師

改土歸流

甘肅 
Ganzi zangzu zizhizhou fuzhouzhang 甘孜藏族自治州副州長

Ganzi zangzu zizhizhou zhengxie 甘孜藏族自治州政協副主席 fuzhuxi

Genzao

根造

Gong Gengyun

壟耕耘

Hai Zhengtao

海正濤

Hainan

海南

He Long

賀龍

Hui

回

Jinshajiang

金沙江

Kangding

康定

Kangding diqu minzu xieshanghui

Kangding junguanhui

Kangren zhi Kang

Lai Zuozhong

Li Kunbi

Li Xianian

Ling Chunsheng

Liu Bocheng

Liu Jiaju

Liu Wenhui

Luding

Ma Bufang

Mao Zedong

minzu

Mixian

Qin Heping

Qinghai

qu fuzhihui

quanguo renda daibiao

Ren Naiqiang

Sichuan

康定地區民族協商會

康定軍管會

康人治康

來作中

李昆壁

李先念

淩純聲

劉伯承

劉家駒

劉文輝

瀘定

馬步芳

毛澤東

民族

密顯

秦和平

青海

區副指揮

全國人大代表

任乃强

四川

Sichuan sheng zhengxie fuzhuxi

四川省政協副主席

taizi

太子

Tongxiao fashi

通孝法師

tubing yingzhang

tusi

土兵營長

土司

Wan Tengjiao

萬騰蛟

Wang Weizhou

王維舟

Xichang

西昌 


$\begin{array}{ll}\text { Xikang } & \text { 西康 } \\ \text { Xikang bao'an xingzhengjiangxihui } & \text { 衛行政講習會 } \\ \text { Xikang sheng canyiyuan } & \text { 西康省參議員 } \\ \text { Xikang sheng fulian } & \text { 西康省婦聯 } \\ \text { Xikang sheng zangzuzizhiqu renmin } & \text { 西康省藏族自治區人民政府 } \\ \text { zhengfu } & \\ \text { Xikang sheng zangzu zizhiqu } & \text { 西康省藏族自治區政協 } \\ \text { zhengxie } & \\ \text { Xikang tezhong bao'anfu duizhang } & \text { 西康特種警衛副隊長 } \\ \text { xinanjunzheng weiyuanhuizhuxi } & \text { 西南軍政委員會主席 } \\ \text { xinan minzu funü lianhehui } & \text { 西南民族婦女聯合會 } \\ \text { xuanjiao shi } & \text { 宣教師 } \\ \text { xuanhua shi } & \text { 宣化師 } \\ \text { Ya'an } & \text { 雅安 } \\ \text { Yajiang } & \text { 雅江 } \\ \text { Yi } & \text { 彝(族) } \\ \text { Zhang Ji } & \text { 張繼 } \\ \text { Zhang Qun } & \text { 張群 } \\ \text { Zhang Ziyu } & \text { 張子愚 } \\ \text { Zhao Erfeng } & \text { 趙爾豐 } \\ \text { zhengjiao heyi } & \text { 政教合一 } \\ \text { Zhonghua quanguofunü lianhehui } & \text { 中華全國婦女聯合會 } \\ \text { Zhu De } & \text { 朱德 }\end{array}$

\section{References}

Anon. 1982. 'Xiage Daoden chuanqi de yi sheng' 夏克刀登传奇的一生 (The Legendary Life of Jagö Topden). https://fengsu.supfree.net/up.asp?id=16192. Accessed 7 June 2019 .

Baima Dengdeng and Xiake Zelang. 2008. 'Dege tusi jiazu neibu jiqi xiashu touren zhijian de fenzheng' (Disputes and Fighting within the Dergé King's Family and with Their Subordinate Headmen), translated by Lang Jia (Namgyel) and Wei Gang, and compiled by Lai Zuozhong. Ganzi zhou wenshi jicui [The Selected Cultural and Historical Materials of Kandzé (Ganzi) Prefecture], vol.1: $185^{-203}$.

Chen Peibin. 2014. 'Minguo kangqu xianzhi yanjiu' (On the County Administration System in the Kham Region in the Period of the Republic of China). Sichuan shifan daxue xuebao (Journal of Sichuan Normal University) 41 (5): 171-176. 
Chengdu junqu silingbu. 1957. Kangqu beibu shehui qingkuang diaocha (Investigation into the Social Conditions of Northern Kham). Chengdu: Chengdu junqu silingbu (For internal circulation only).

Chung Tsering (trans.). 2006. Bod migsar brje bazhig (A Tibetan Revolutionary). Da ram sa la: Bod kyi dus bab.

Coleman, William M. 2014. Making the State on the Sino-Tibetan Frontier: Chinese Expansion and Local Power in Batang, 1842-1939. PhD Dissertation, Columbia University.

Deng Junkang and Li Kunbi. 2009. 'Xike daodeng' (1900-1960) (Jagö Topden [19001960]). Ganzi Zangzu zizhizhou wenshi jicui (The Selected Cultural and Historical Materials of Kandzé [Ganzi]), vol. 2 (part 2): 188-192.

Du Yongbin. 1989. 'Dege tusi xiaqu de zhengjiao jiqi tedian' (The Politics and Religion as Well as Their Features in the Territory under the Jurisdiction of the Dergé King). Zhongguo zangxue (China Tibetology) 3: 85-99.

Duan Jinsheng. 2014. 'Difang yishi yu defang zhengzhi: zhengzhi quyuhua changing xia biangjiang zhili-yi' (The Local Consciousness and the Local Politics: Borderland Governance in the Context of Political Regionalism - Focusing on Yunnan during the Period of Nanjing Government). Zhongguo bianjiang shidi yanjiu (China's Borderland History and Geography Studies), 24 (1): 31-40.

Feng Youzhi.1994. Xikang shi shiyi: wenshi ziliao (Supplemental History of Xikang: Historical Document). Kangding: Zhongguo renmin zhengzhi xieshang huiyi Sichuan sheng Ganzi zagnzu zizhizou weiyuanhui.

Ge Le (Dge legs). 1984. Ganzi zangzu zizhizhou shihua (History of Kandzé (Ganzi) Tibetan Autonomous Prefecture). Chengdu: Sichuan minzu chubashe.

Genzao Fashi and Mixian Fashi. 1995. Qiufa huiyi lu (Memoirs of Seeking for Dharma). New York: Da Yuanman xinsui yanjiu zhongxin (Maha Sandhi Yoga Center). Goldstein, Melvyn C. 1989. A History of Modern Tibet, 1913-1951: The Demise of the Lamaist State. Berkeley: University of California Press.

Goldstein, Melvyn C., Dawei Sherap and William Siebenschuh. 2004. A Tibetan Revolutionary: The Political Life and Times of Bapa Phüntso Wangyé. Berkeley: University of California Press.

Goldstein, Melvyn C., T. N. Shelling and J. T. Surkhang. 2001. The New Tibetan-English Dictionary of Modern Tibetan. Berkeley: University of California Press.

Gros, Stéphane. 2016. 'Introduction to "Frontier Tibet: Trade and Boundaries of Authority in Kham"'. Cross-Current: East Asian History and Culture Review 5 (2): 209-238.

Hartley, Lauren. 1997. A Socio-Historical Study of the Kingdom of Sde-dge (Derge, Kham) in the Late Nineteenth Century: Ris-med Views of Alliance and Authority. MA Thesis, Indiana University. 
Jiang Anxi, Lai Zuozhong and Deng Junkang. 1983. 'Nuona shibian jilüe' (A Brief Account of the Nörla Incident). Sichuan wenshi ziliao xuanji (The Selected Cultural and Historical Materials), vol. 29, 64-77. Chengdu: Sichuan renmin chubanshe.

Kangding minzu shizhuan xianxiezu. 1994. Ganzi zangzu zizhizhou minzuzhi (History of Nationalities in Kandzé Tibetan Autonomous Prefecture). Beijing: Dangdai Zhongguo chubanshe.

Karma Gyeltsen. 1994. Sde dge chos 'byung (History of Buddhism of Dergé). Hang kong: Ya gling dpe skrung khang.

Kongtrül Yönten Gyatso and Karma Trinlé. 1997. Kong sprul yon tan rgya mtsho'I rnam thar (Autobiography of Kongtrül Yonten Gyatso). Khren du'u: Si khron mi rigs dpe skrun khang.

Lai Zuozhong. 1996. 'Xiake Daodeng zhuanlüe' (A Short Biography of Jagö Topden). Sichuan sheng wenshi ziliao jicui (minzu zonjiao, huaqiaobian) (The Selected Cultural and Historical Materials of Sichuan Province [The Edition about Ethnic Minorities, Religion and Overseas Chinese]), vol.5, 97-101. Chengdu: Sichuan renmin chubanshe.

Lhalung Chimé Dörjé and Dayang. 2009. Khams sde dge rgyal po'i srid don lo rgyus (A Political History of the Dergé Kings of Kham). Be cin: krung go'i bod kyi shes rig dpe skrun khang.

Li Xiannian zhuan bianxiezu. 2011. Li Xiannian nianpu (diyi juan) (Chronology of Li Xiannian), vol. 1. Beijing: Zhongyang wenxian chubanshe.

Lin Chunsheng. 1944. 'Zhongguo bianzhen zhi tusi zhidu' (The Tusi System in China's Frontier Towns). Bianzheng gonglun (Research on Frontier Affairs) 2-3: 8-9.

Lin Junhua. 1993. 'Ganzi zangqu xuexiao jiaoyu kaifa shi gaisuo' (A Study of the Development History of School Education in Kandzé (Ganzi) Tibetan Region). Xizang yanjiu (Tibetan studies) 2: 39-46, 17.

Liu Xianqiang. 2007. 'Er-shi shiji shang banye kangqu shifan jiaoyu fazhan shulun' (On the Development of Normal Education in the Kham Region in the First Half of the Twentieth Century). Xizang yanjiu (Tibetan Studies) 1: 90-95.

Liu Xianqiang. 2008. 'Er-shi shiji shang banye Kangqu xuexiao jiaoyu yanjiu' (A Study of School Education in the Kham Region in the First Half of the Twentieth Century). PhD dissertation, Sichuan University.

Lodrö Püntsok. 1994. Sde dge’i lo rgyus (History of Dergé). Dgon chen: Srid gros Sde dge rig gnas lo rgyus rgyu cha bsdu sgrig u yon lhan khang.

Lodrö Püntsok, Samten, Tsewang Tashi, Jangchuk Chömpel, Dönwang, Ngawang Tendzin and Pema Dönden. 1995. Sde dge rig gnas dang lo rgyus (Culture and History of Dergé). Dgon chen: Srid sgros sde dge rdzong rig gnas lo rgyus o yon lhan hang. 
Lu Chuanlin. 2001a. 'Xiangchen chouban Dege tusi shiqing, tongguan jici qingzha, qingci xinren duchen chabanshu' (Memorial with a Detailed Report about the Actual State of Affairs Concerning Dealing with the Dergé Tusi, the In-fighting by my Colleagues with Excuses and Requesting to Order the Newly Appointed Governor-general to Investigate and Deal with Accordingly).Jindai Kangzang zhongda shijian xuanbian (Selected Important Events of Modern Kham and Central Tibet) (Part One), vol.1: 474-479. Lasa: Xizang guji chubanshe.

Lu Chuanlin. 20o1b. 'Chaban De-er ge-te tusi xiandi guicheng, qing xu gaitu, bingshang chuli renyuan zhoupian' (Memorial Concerning Investigating and Handling the Dergé Tusi's Offering his Land and Submitting, Requesting to be Allowed to Carry out the Policy of 'Substituting Chieftains with State Appointed Civilian Officials' and Rewarding Those People Who Have Exerted Themselves in Connection to the Matter).Jindai Kangzang zhongda shijian xuanbian (Selected Important Events of Modern Kham and Central Tibet) (Part One), vol.1: 467-470. Lasa: Xizang guji chubanshe.

Luo Shaoming. 2015. 'Minguo shiqi de kangzang jingying yu 'kangren zhikang' yundong' (The Khampa Elite and the Movement of the 'Khampa Rule of Kham' during the Republican Period). Sichuan minzu xueyuan xuebao (Journal of Sichuan University for Nationalities) 24 (3): 1-5.

Ma Guangwen. 2001. 'Shu Fuhe xie Ma Guangwen bing Dege tusi zhengxi an' (The Report about the Case of Contention for the Position of the Dergé Tusi by the Acting Commander of Fuhe Division). Jindai Kangqzang zhongda shijian shiliao xuanbian (diyi bian: shang) (Selected Important Events of Modern Kham and Central Tibet) (Part One), vol.1. Lasa: Xizang guji chubanshe.

Ma Tinzhong. 2008. 'Lun minguo shiqi Ganzi diqu de xuexiao jiaoyu' (On School Education of Kandzé (Ganzi) Region during the Republican Period). Xinan minzu daxue xuebao (Journal of Southwest University for Nationalities) 5:68-74.

Ma Tinzhong. 2012. 'Minguo shiqi Xikang sheng minzu jiaoyude fazhan' (On the Development of Education for Ethnic Minorities in Xikang Province during the Republican Period).Xinan minzu daxuexuebao (Journal of Southwest University for Nationalities) 12: 205-209.

McGranahan, Carole. 2005. 'In Rapga's Library: The Texts and Times of a Rebel Tibetan Intellectual'. Cahiers d'Extrême-Asie 15 (1): 253-274.

Meilang Zongzhen (Mönlam Tsöndrü). 2005a. "Bangdacang” fanpan gaxia zhengfu shimo kao' (A Study of the Whole Story of the Pangda Family's Revolt against the Tibetan Government). Xizang Yanjiu (Tibetan Studies) 4:15-21.

Meilang Zongzhen (Mönlam Tsöndrü). 2005b. 'Cong "liulang shangren” dao Gaxia zhengfu de "shangshang" - Bangda Nyijiang kao' (From an Itinerant Trader to the Trade Agent of the Tibetan Government - A Atudy of Pangda Nyigyel). Xizang daxue xuebao (Journal of Tibet University) 20 (3): 50-55. 
Meilang Zongzhen (Mönlam Tsöndrü). 20o9. 'Lun er-shi shiji sanshi sishi niandai de Bangda Duoji' (On Pangda Topgyé in 1930s and 1940s). Xizang yanjiu 1: 71-80. Peng, Wenbin. 2002. 'Frontier Process, Provincial Politics and Movements for Khampa Autonomy During the Republican Period'. Khams pa Histories: Visions of People, Place and Authority, edited by Lawrence Epstein, 57-84. Leiden: Brill. Qin Heping. 2007. 'Xiangcheng tutou tongzhi de youlai jiqi shanbian' (Origins and Changes of the Rule by the Indigenous Leaders in Xiangcheng). Xizang yanjiu (Tibetan Studies) 2: 1-9.

Qin Heping. 2014. 'Cong fandui tusi dao jiehou minzhu gaige - guanyu Xiake Daodeng de yanjiu' (From Opposing the Tusi to Accepting the Democratic Reform - A Study of Jagö Topden). Zhongguo zangxue (China Tibetology) 1: 65-79.

Ren Naiqiang. 2009. 'Dege tusi shipu' (The Genealogy of the Dergé Kings). In Ren Naiqiang zangxue wenji (The Selected Tibetan Studies Works by Ren Naiqiang), vol.3, 166-192. Beijing: Zhongguo zangxue chubanshe.

Rockhill, William W. 1891. The Land of Lamas: Notes of a Journey through China Mongolia and Tibet. New York: The Century Co.

Ronis, Jann. 2011. 'Powerful Women in the History of Dege: Reassessing the Event of Reign of the Dowager Queen Tsewang Lhamo (d.1812)'. Revue d'Etudes Tibétaines 21: 61-81.

Sichuan sheng Dege xianzhi bianzuan weiyuanhui. 1995. Dege xianzhi (Gazetteer of Dergé County). Chengdu: Sichuan renmin chubanshe.

Tsewang Dörjé Rikdzin. 1989. Sde dge rgyal rabs (Genealogy of the Dergé Kings). Khren du'u: Si khron mi rigs dpe skrun khang.

Tsomu, Yudru. 2013. 'Taming the Khampas: The Republican Construction of Eastern Tibet'. Modern China, 39 (3): 319-344.

Tsomu, Yudru. 2015. The Rise of Gönpo Namgyel in Kham: The Blind Warrior of Nyarong. Lanham, MD: Lexington Books.

Tsomu, Yudru. 2016. 'Traders as Cultural Brokers on the Sino-Tibetan Borderland During the Republican Period'. Zangxue xuekan (Journal of Tibetan Studies) 14: 177-210.

Tsomu, Yudru. 2018. 'Women as Chieftains in Modern Kham History'. Inner Asia 20: 107-131.

Tubten Püntsok. 2010. Sde dge'i lo rgyus spyi don zla 'od gsar ba'i me long (History of Dergé). Lha sa: Bod ljongs mi dmangs dpe skrun khang.

Tuttle, Gray. 2013. 'Uniting Religion and Politics in a Bid for Autonomy: Lamas in Exile in China and America'. The Tibetan History Reader, edited by Tuttle, Gray and Kurtis R. Schaeffer, 561-582. New York: Columbia University Press.

van Spengen, Wim. 2002. 'A Glimpse of Ethnicities and Societies on the Frontier Through European Travel and Historical Literature in Southern Khams'. Khams 
pa Histories: Visions of People, Place and Authority, edited by Lawrence Epstein, 7-29. Leiden: Brill.

Wang Chuan. 2009. 'Liu Wenhui yu Xikang diqu wangchuan fojiao jie guanxi sulun' (An Account of Liu Wenhui and his Relationship with the Tibetan Buddhist Circle in Xikang). Zhongguo Zangxue (China Tibetology) 3 (2006): 78-84.

Wang Di. 1986. 'Qingmo chuanbian xingxue gaishu' (A Brief Account of Promoting Education in the Sichuan Borderlands at the End of the Qing Period). Xizang yanjiu (Tibetan Studies) 2: 55-62.

Wang Haibing. 2013. 'Luanshi qiucun: minguo shiqi Xiangcheng diqu de tutou tongzhi' (Struggling to Survive at Trouble Times: The Rule of Indigenous Leaders in Chaktreng (Xiangcheng) during the Republican Period). Xinan minzu daxue xuebao (Journal of Southwest University for Nationalities) 6: 69-74.

Wang Juan. 2013. 'Bianjiang zizhi yundong zhong de defang chuantong yu guojia zhengzhi - yi er-shi shiji sanshi niandai de sanci "kangren zhikang" yundong wei zhongxin' (The Regional Tradition and the National Politics in Movements for Borderland Autonomy: Focusing on the Three Movements for 'the Khampa Rule of Kham' in 1930s). Xinan minzu daxue xuebao (Journal of Southwest University for Nationalities) 12: 25-30.

Wu Dianyao. 2006. Zhu De nianpu (xinbianben) (The Chronology of Zhu De) (New Edition). Bejing: Zhongyang wenxian chubanshe.

Wu Fengpei. 1984. Zhao Erfeng chuanbian zoudu (Zhao Erfeng's Memorials of the Sichuan Borderland). Chengdu: Sichuan renmin chubanshe.

Xiake daodeng (Jagö Topden).199o. 'Shi'er yue Xiake Daodeng dian' (The Telegram Sent by Jagö Topden [to Liu Wenhui, the Chairman of Xikang Province] in December [1939]).Jindai Kangqu dang'an ziliao xuanbian (The Selected Archives of Modern Kham). Chengdu: Sichuan daxue chubanshe.

Xiake Daodeng [Jagö Topden]. 199o. 'Shi-er yue Xiake Daodeng dian' (The Telegraph Sent by Jagö Topden in December [1939]). Jindai Kangqu dang'an ziliao xuanbian (The Selected Archives of Modern Kham). Chengdu: Sichuan daxue chubanshe.

Xue Jiangang. 2013. Shilun Qingmo Zhao Erfeng chuanbian xingxue jiqi yingxiang (19o6-1911) (A Tentative Discussion of Promoting Education by Zhao Erfeng in the Sichuan Borderlands and its Impact). MA thesis, Zhongyang minzu daxue.

Yelé Tsültrim, n.d. Lcags mdud mgon rnam pa’i lo rgyus rag rim brjod pa (A Brief Account of the History of Chakdü Gönpo Namgyel). Unpublished manuscript. You Zhen. 2010. 'Quanli zhengzhi yu defang zizhi: er-shi shiji sanshi niandai de kangren zhikang yundong' (Power Politics and Regional Autonomy: The "Khampa Rule of Kham" Movement in the 1930s). Xizang daxue xuebao (Journal of Tibet University) 25 (3): 104-108. 
Zeng Wenqiong. 1988. 'Lun kangqu de zhengjiao lianmeng zhidu' (On the System of Alliance between Politics and Religion). Xinan minzu daxue xuebao (Journal of Southwest University for Nationalities) 2: 17-25.

Zewang Dengdeng [Tsewang Düdül]. 199o. 'Shi'er yue shisan ri Zewang Dengdeng dian' (The Telegram Sent by Tsewag Düdül on December 13 [1939]).Jindai Kangqu dang'an ziliao xuanbian (The Selected Archives of Modern Kham). Chengdu: Sichuan daxue chubanshe.

Zhang Faxian. 2011. 'Jindai Xizang jushang bangdacang' (Pangdatsang, the Great Trader's Family in Modern Tibet). Xizang minzu xueyuan xuebao (Journal of Tibet Nationalities Institute) $3^{2}$ (2): 25-30, $13^{8}$.

Zhang Jingxi. 1939. Sanshi nian lai zhi Xikang jiaoyu (shangjuan) (Education of Xikang for the Past 30 Years), vol. 1. Shanghai: Shangwu yinshuguan.

Zhao Erfeng. 2001. 'Zhao Erfeng dian Zhao Erxun, gao zunzhi jinjiao Ang ni, bing chuanyu Zhandui fanguan, qing daizou dian' (Zhao Erfeng's Telegraph to Zhao Erxun Reporting his Attack against the Rebel Ngawang Jampel Rinchen upon the Imperial Order, Instructing the Tibetan Commissioner Stationed in Nyarong and Requesting to Memorialize on his Behalf). In Jindai Kangzang zhongda shijian xuanbian (Selected Important Events of Modern Kham and Central Tibet) (Part One), vol.1, 504-505. Lasa: Xizang guji chubanshe.

Zhonggong Ganzi zhouwei dangshi yanjiushi. 2012. Hongjun changzheng zai Ganzi zangqu (di'er bian) (The Red Army's Long March in Kandzé (Ganzi) Tibetan Region). (2nd edition). Chengdu: Chengdu keji daxue chubanshe.

Zhonggong Ganzi zhouwei zuzhibu. 1991. Zhongguo gongchadang Sichuan sheng Ganzi zangzu zizhizhou zhuzhi shiliao (The Selected Historical Materials of the Organization of the Kandzé (Ganzi) Tibetan Autonomous Prefecture, Sichuan Province of the Chinese Communist Party). Chengdu: Sichuan renmin chubanshe.

Zhongkeyuan minzu yanjiusuo Sichuan diaochazu. 1963. Dege diqu shehui diaocha baogao (The Report of the Social Investigation of the Dergé Region).

\section{About the Author}

YUDRU TsOMU received her PhD in 2006 from Harvard University in the field of Tibetan Studies and was a postdoctoral fellow at Stanford University in 2007. Her research interest includes Tibetan history, in particular the history of Kham, the study of Tibetan society in Kham as well as cultural interaction and blending in the Sino-Tibetan borderlands. Her present project is entitled 'Eastern Tibet in the Eyes of Chinese Intellectuals during the Republican Period', funded by the Chiang Ching-Kuo Foundation, the 
American Philosophical Society, and the American Council of Learned Society. Her monograph entitled The Blind Warrior of Nyarong: The Rise of Gönpo Namgyel in Kham was published by the Lexington Books in 2015. She has presented her research work at major international academic conferences, and has published articles in English and Chinese, including 'Constructing Images of Mgon po rnam rygal: a Hero or a Villain?' in Revue d'Etudes Tibétaines (2012); 'Taming the Khampas: The Republican Construction of Eastern Tibet', in Modern China (2012). 
